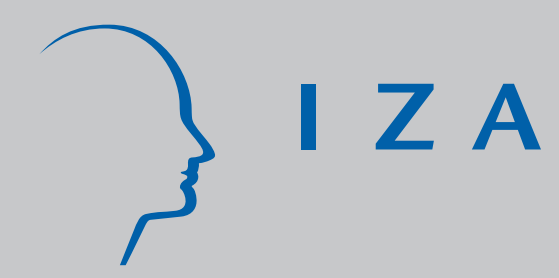

IZA DP No. 252

Inequality and Income Distribution in Georgia

Ruslan Yemtsov

J anuary 2001 


\title{
Inequality and Income Distribution in Georgia
}

\author{
Ruslan Yemtsov \\ World Bank, Washington, D.C. and IZA, Bonn \\ Discussion Paper No. 252 \\ January 2001 \\ IZA \\ P.O. Box 7240 \\ D-53072 Bonn \\ Germany \\ Tel.: +49-228-3894-0 \\ Fax: +49-228-3894-210 \\ Email: iza@iza.org
}

This Discussion Paper is issued within the framework of IZA's research area Labor Markets in Transition. Any opinions expressed here are those of the author(s) and not those of the institute. Research disseminated by IZA may include views on policy, but the institute itself takes no institutional policy positions.

The Institute for the Study of Labor (IZA) in Bonn is a local and virtual international research center and a place of communication between science, politics and business. IZA is an independent, nonprofit limited liability company (Gesellschaft mit beschränkter Haftung) supported by the Deutsche Post AG. The center is associated with the University of Bonn and offers a stimulating research environment through its research networks, research support, and visitors and doctoral programs. IZA engages in (i) original and internationally competitive research in all fields of labor economics, (ii) development of policy concepts, and (iii) dissemination of research results and concepts to the interested public. The current research program deals with (1) mobility and flexibility of labor markets, (2) internationalization of labor markets and European integration, (3) the welfare state and labor markets, (4) labor markets in transition, (5) the future of work, (6) project evaluation and (7) general labor economics.

IZA Discussion Papers often represent preliminary work and are circulated to encourage discussion. Citation of such a paper should account for its provisional character. 
IZA Discussion Paper No. 252

January 2001

\title{
ABSTRACT \\ Inequality and Income Distribution in Georgia
}

In the period of macroeconomic crisis in Georgia between 1991 and1994 the combination of hyperinflation, catastrophic output drop and weak governance, have led to a sharp rise in inequality among households. Sharp inequities have arisen not only between households, but also between regions. This paper gives a picture of the main channels of redistribution and of the main driving forces of income inequality in Georgia, as it emerges from the analysis of the first representative survey of incomes and expenditures of Georgian households in 1996-1997. The paper finds that the level of inequality for money income in Georgia is comparable to highest inequality countries of Latin America (Gini equals 0.6). However, given the degree of informalization and demonetization of the economy, measuring only reported monetary incomes gives a somewhat misleading picture of the living standards. The paper argues that consumption is a much better indicator of welfare, especially in the Georgian context and explores the relationship between income and consumption in the Georgian context. Using consumption, we get the picture that is marked by very clear, though, not as striking inequalities (Gini coefficient of 0.36). Growth has not yet had a strong impact on consumption inequality per se, but we find evidence that during 1996-97 consumption increased at almost all levels of the distribution. During the same period, there was significant income mobility, except for those at the very bottom or the very top of the income distribution. For the latter, economic success appears to be closely associated with labor market status, ownership of productive assets and resulting earnings opportunities. Georgian economy is generating a system of much inequality. The key share of inequality can be attributed to informal incomes (using the decomposition analysis as proposed by Shorrocks). State transfers being reduced to minimum levels do exercise only a slight positive impact on the overall inequality outcomes.

JEL Classification: $\quad$ I3, J4

Keywords: Inequality, returns to education, in-kind income, poverty, income mobility, Gini coefficient, unreported incomes, Theil entropy index, mean log deviation index, decomposition of inequality, inequality between groups

\author{
Ruslan Yemtsov \\ World Bank \\ 1818 H Street N.W. Room H4-239 \\ Washington D.C. 20433 \\ USA \\ Tel.: +1-202-458-7276 \\ Fax: +1-202-522-2755 \\ Email: Ryemtsov@worldbank.org
}




\section{Inequality and Income Distribution}

In the period of macroeconomic crisis of 1991-1994, the combination of hyperinflation, drop in output and weak governance, led to a sharp rise in inequality among households, with a fast accumulation of wealth at the top of the income distribution going hand in hand with the impoverishment of those at the bottom. Sharp inequities have arisen not only between households, but also between regions. The Gini coefficient for income at 0.6, as observed in 1996, is on a level comparable to countries of Latin America with the highest levels of inequality. However, given the degree of informalization and de-monetization of economy, measuring only reported monetary incomes gives a somewhat misleading picture of the standard of living. Consumption is a much better indicator of welfare, especially in the Georgian context. Using consumption, we see a picture that is marked by very clear, though not as striking, inequalities (Gini coefficient of .36). The economic growth has yet to strongly impact on inequality, which remains practically stable over the period of observation. But behind this stable inequality there are large fluctuations and high volatility in the position of households. Though stabilization has indeed been associated with a decline in the incidence of poverty, the Georgian economy is generating a system of much inequality; there are clearly groups in the population who suffer from chronic poverty, and the State transfers being reduced to minimum levels has only a slight positive impact on the overall inequality outcomes. Thus, making the group of those who benefit from growth as large as possible is a clear challenge for policy makers.

\subsection{Inequality in consumption and incomes in Georgia}

1. This section is aimed at establishing basic facts about the inequality of living standards in Georgia. It is based on the SDS household survey data, - the same source that was used in the analysis of poverty and labor markets. Both income and consumption data are comprehensive indicators of welfare that include monetary and in-kind components averaged over the last three months for each household. We are going to use mostly consumption data as it is more reliable in the environment of unstable incomes and in a large informal economy. However, using the income measure facilitates comparability with other estimates, including those for other countries or pre-transition. This is something that we are going to present as well. Our results are reported using nominal values. This is possible because of the absence of significant variation in price levels across regions, and because of low inflation. We report per capita and household measures as well as taking a look at the sensitivity of our results to changes in equivalence scales. We also look at the degree of mobility of households associated with changes in the consumption over time by exploring the panel component of the dataset.

2. Matching consumption with incomes. Table 1 presents a first look at the main parameters of distribution in Georgia. The most striking feature of this data is the unusually high discrepancy between total consumption and income (over 40 percent on average). Table 1 also shows that the gap is roughly constant over time. Such a high and persistent discrepancy cannot be found in any other FSU country (cf. Milanovic (1998), section 5.2). What is important for our analysis is that the picture of inequality as revealed by consumption is very different from inequality emerging from income data, as the ratio of medians to means suggests.

The gap between median consumption and income is also high, suggesting that the observed discrepancy is not due to some outliers. In observing this gap by consumption quintiles, we find that it affects all quintiles in more or less, a similar way. Note that since we include in-kind 
consumption in both total consumption and total income, this gap has nothing to do with the fact that a substantial part of consumption in Georgian households is of agricultural products consumed in-kind. As a matter of fact, almost all of the discrepancy we observe is between the total reported cash income and the total reported cash expenditures.

3. Therefore, a closer look at this gap and its determinants is warranted. It is widely accepted in the literature that income data from surveys tends to underestimate "true" welfare. This is because people tend to hide their sources of income and thus underreport them. They are less careful when asked to remember or record (keeping a diary of consumption), their expenditures. Another reason is seasonal or sudden variation of income that households tend to spread over the period ${ }^{1}$. Both reasons are relevant for certain forms of employment that are especially prone to underreport income, and which are particularly widespread in Georgia ${ }^{2}$.

Figure 1. Income and consumption by consumption and income ventiles a) Consumption ranking b) Income ranking

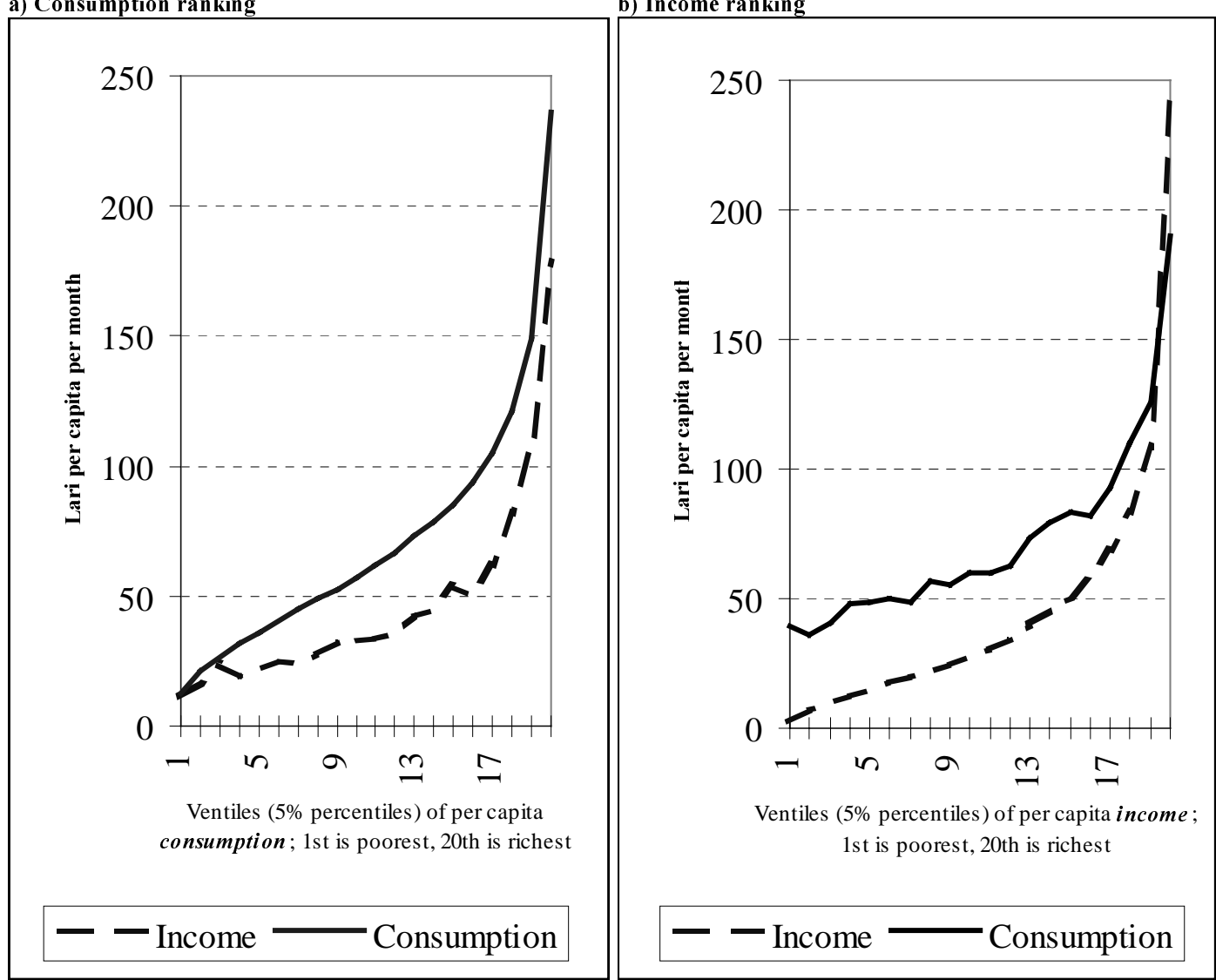

Note: average over period of observations, first interview for each household are used to avid double counting.

1 This reason, while valid for individual households in explaining the gap between income and consumption, is rather dubious while explaining the discrepancies in averages over the period of one year for the whole population.

2 Atkinson, Rainwater and Smeeding (1995) found that even in established market economies the self-employment income tends to have the largest underreporting (compared to national accounts data), - up to 60 percent in West Germany. 
4. Figure 1 provides striking evidence of the pattern of income underreporting in Georgia. The individuals are ranked on the horizontal axis by their consumption (panel a) or income (panel b). By observing panel $b$, we find that only at the highest level of income (for the top 10 percent), reported income and consumption move together. Another striking fact is revealed by the situation in the lowest half of the distribution. While the reported average income is very low, the reported consumption is not dramatically different from the mean. When we do the comparison of reported income and consumption by consumption ventiles (Figure 1 panel a), we find that most of the underreporting is concentrated among households in the middle of the distribution. In fact, for the poorest and the richest, underreporting is not a large distortionary factor in the measurement of welfare, but for the majority of Georgian households it is.

5. One of the reasons why the gap between total cash expenditures and total all-inclusive cash income or cash revenues may rise, is because households use previously accumulated cash holdings to pay for some of their purchases. When we restrict our attention to households for which we have continuous observation throughout the whole year (3 panel waves), rather contrary to the cash holding use hypothesis, we find that the households were consistently having a higher outflow of cash than an inflow. Of course there is a probability that households have accumulated enough savings before they entered the survey, but the sheer size of the accumulated gap over the period of one year - about 1000 lari per household on average - makes this explanation extremely unlikely.

6. Thus, it is plausible to attribute most of the gap between observed monetary spending and monetary total revenues to underreporting. By looking at the discrepancy between total cash expenditures and total reported income by sector of employment, we find several reasons behind the observed gap (Table 2). First, let's notice that the absolute value of underreported cash income is largest where we could have expected it to be: among those employed in restaurants and hotel businesses, where tips are a substantial part of incomes, yet obviously never fully reported. Second, the largest values emerges for health care, where again out-of pocket informal payments from patients and their relatives are an "established" form of income for health care personnel. Relatively high values for the unreported incomes among those employed in transportation are again no surprise. But the fact that Government employees are among the top recipients of unrecorded income is informative, and conveys the presence of corruption. Substantial values for those households that do not have anyone employed are probably due to the very poor reporting of remittances in the survey. Finally, the lowest values for the gap are found in agriculture, where opportunities for all kinds of truly "informal" activities are very limited, and in a small modern sector of financial services and real estate, have the highest "formalization" of their employees' income.

7. Going a step further, we can try to match survey-generated welfare measures with national accounts data. Due to limited information on personal income, we have to limit our comparison to large GDP aggregates. Here the situation is revealing. Average per capita consumption for 1997, as observed in the survey, almost perfectly matches GDP at factor cost per capita, while income falls short to match any GDP-based measure.

8. Let's summarize the findings on the income-consumption gap. First, the observation of the evolution of the gap in the panel component of data suggests that it is clearly a result of underreporting. Second, decomposition of the gap by sectors of employment shows that the underreporting is positively and very closely associated with the degree of informalization in each sector, and with the prevalence of "gray" or even "black" economic transactions. Changes in the gap over time show that it is a surprisingly stable component of total income. Finally, 
based on comparisons with GDP data we have to admit that using the total reported incomes indicator is misleading, while on the other hand, consumption data gives a much more accurate match to national accounts.

9. Based on that evidence, we are bound to make adjustments to raw data on incomes by households. The simplest way to adjust income while preserving most of the information contained in the data, is to impute "unrecorded" income as a difference between total money spending and total money revenues of a household whenever the former exceeds the latter. This adjustment affects about 90 percent of households in each round, of which about half are quite substantially affected.

10. Using imputed rather than reported data has a profound consequence for income-based measures of inequality. As we have seen, since most of "unreported" income is concentrated in the middle of the distribution, we are going to see a strong equalizing effect of this imputation. Figure 2 illustrates this point.

Figure 2. Lorenz curve for monetary income and concentration curves for consumption and "unreported" monetary incomes

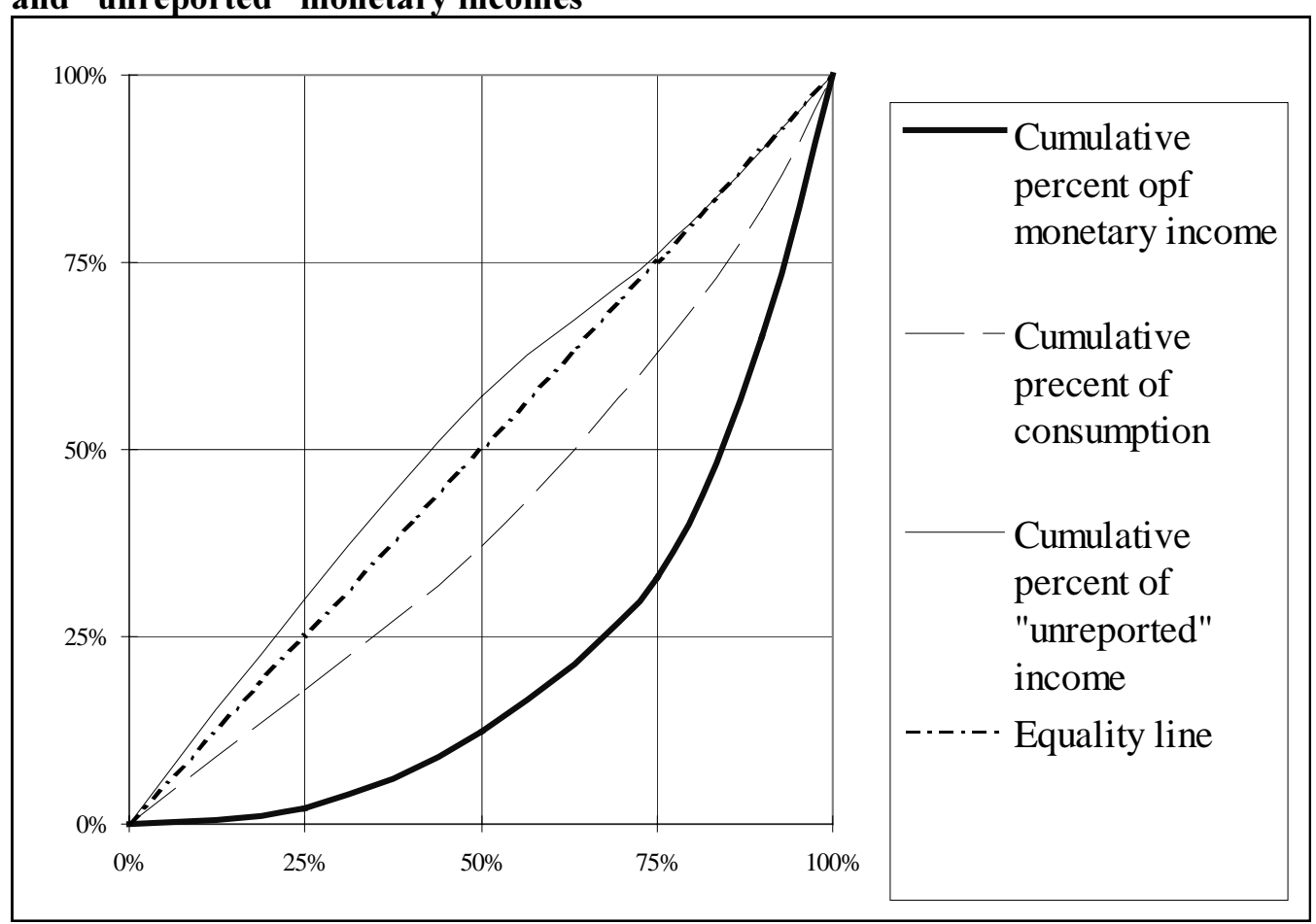

Source: SDS household survey data, pooled for all quarters of the survey, using only first interviews.

11. As we see from Figure 2, monetary reported incomes tend to be extremely unequally distributed. Concentration curve for "unreported" incomes with respect to reported monetary incomes in fact lies above the equality line, suggesting that "hidden" income is a progressive component of total income. The resulting concentration curve for total income (including imputed income) is very close to the concentration curve for consumption as shown. 
12. However, the observed striking inequality in money incomes is an important property of data, and reveals some important structural features of the Georgian economy. Moreover, most of the data on other countries is presented in the form of monetary incomes. Therefore, later we will look at the distribution of monetary incomes in more detail, after we analyze in depth a more adequate measure of well-being - consumption.

\section{Inequality in consumption}

13. Looking at the evolution of mean per capita consumption by quintiles as reported in Table 1, we find significant and persistent, yet not striking, inequalities in real consumption across all quintiles. Consumption inequality is not large; significantly smaller in effect than estimates of income inequality would suggest. All parts of the distribution experienced a growth in consumption if we relate 1997 to corresponding periods of 1996. The important point to note, however, is the variation over time in the evolution of mean incomes and consumption by quintiles. The incomes did not follow as a clear trend, as did consumption. Even consumption has been showing considerable fluctuations. Over the full period from 1996-1997, despite an upward trend, there has been, for example, a universal drop between the 3rd and 4th quarters of 1996. Medians for both income and consumption remained significantly below corresponding means. This is especially clear for income with a median at around 60-64 percent of the average, indicating clear skewedness to the right in the income distribution.

14. Table 3 brings us a step further by pulling together some standard summary statistics for both per capita and household measures as well as consumption shares by quintiles over time. Turning to this more detailed picture of inequality by consumption, we find further evidence for the support of the stability in the overall distribution of the population or households by the level of consumption. Despite some signs of increasing share of total consumption to the lowest quintile, there is a constant share for the lowest 5 percent. On the opposite, the small drop in the share of the upper quintile is almost exclusively due to the losses at the very top of the distribution.

15. The measures of inequality - the Gini coefficient, the Theil indices, and the coefficient of variation - tell a similar story. By the end of 1997, the Georgian per capita Gini for consumption was around 0.36 . The Gini for total household consumption shifted very slightly from 0.39 to 0.38 in the same period. This is comparable to the inequality in consumption observed in Indonesia or Vietnam (countries that are marked by considerable inequities) and much higher than in any country in Europe. The level of inequality in consumption observed in Georgia is now quite close to the levels observed in Latin American countries for which its starts at about 0.4 .

16. The other feature is a slight decline in inequality over the period. Figure 3 brings this point home. It shows that almost the whole distribution curve has shifted to the right, indicating that we observe an increase in consumption almost over the whole range of distribution. There is also a small drop in inequality, as the distribution curve for the first observation point is slightly wider than the final curve. 
17. The very slight drop in inequality over one and a half years of observation is further supported by three indices of inequality sensitive to different parts of the distribution ${ }^{3}$. Theil mean $\log$ deviation measure, Theil entropy measure and the coefficient of variation for both per capita and household measures, all tell a compelling story of a very slight improvement over the entire spectrum of the distribution ${ }^{4}$. The change in inequality, however, is not monotonic, with a slight rise in the last period.

18. Income and consumption data for the transition economies have historically been presented in per capita form. While, as expected, we find that inequality is sensitive to the choice of equivalence scale, it is also evident that whichever equivalence scale is applied, a picture of stable inequality holds. We find a usual U-shaped relationship between the values of inequality indices and degree for economies of scale adjustment, with rather limited magnitudes of impact of economies of scale adjustment on inequality. Thus, for the theta and equivalence scale that were used for poverty analysis the Gini for consumption per equivalent adult is 2-3 percentage points lower than the Gini for per capita consumption (by the last round .33 as opposed to .36), and this level is close to the absolute minimum for the whole range of adjustment for economies of scale (ranging from no adjustment, as in per capita measurement, or $\theta=1$, to assuming full adjustment, measuring inequality between households regardless of their size, $\theta=0)$. In terms of levels of inequality, we find that for households $(\theta=0)$ there is a notably higher level of initial inequality and a somewhat more ambivalent changes over time.

Figure 3. Distribution of the population by per capita consumption: comparing first and last rounds (log scale)

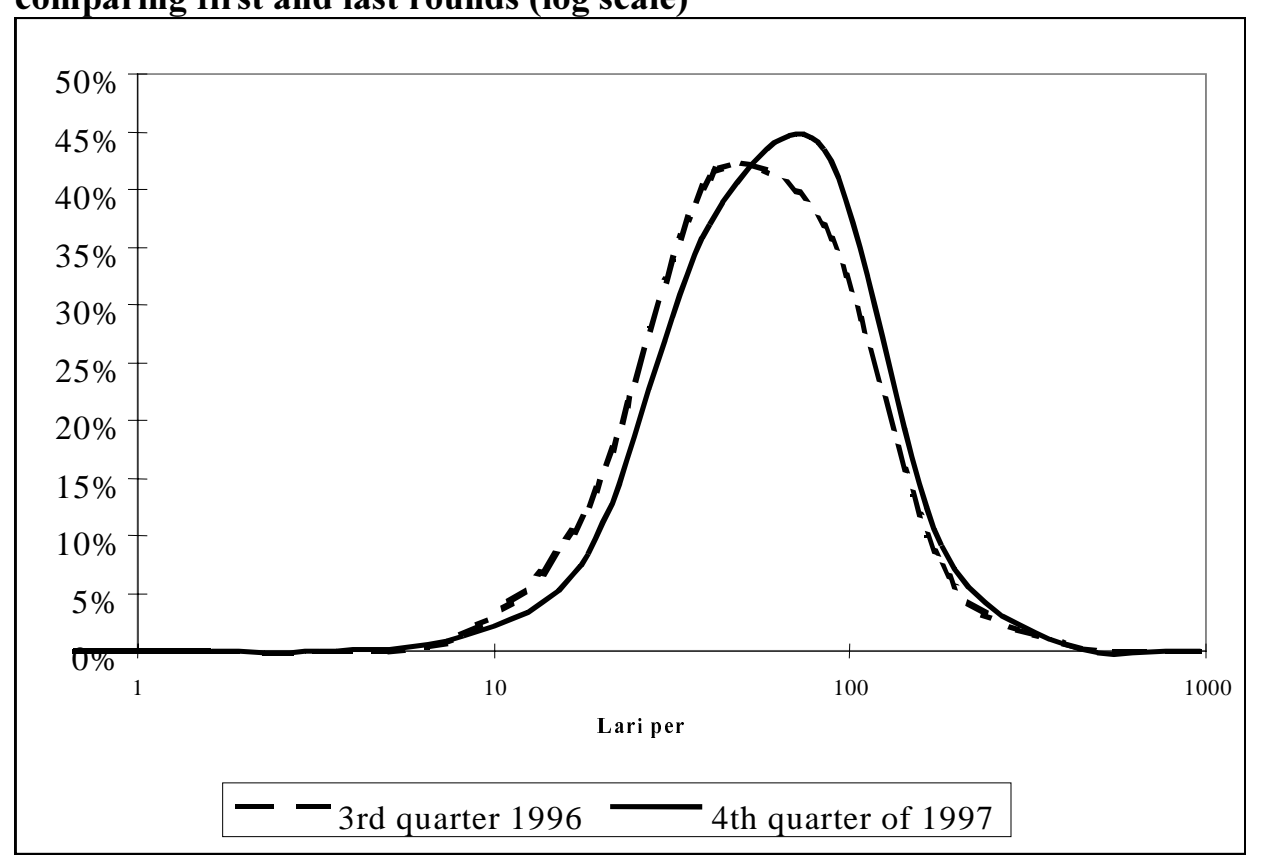

Source: SDS household data; kernel procedure to obtain density estimates.

Mobility

3 Gini index is mostly sensitive to the inequality in the middle of the distribution; Theil mean log deviation index - to the inequality between the poor; coefficient of variation - to the inequality between the rich; and Theil entropy index is equally sensitive to the distribution in all parts of the spectrum.

4 Note that the change is greater than a standard error taking into account by the survey sample design, which means that we do in fact observe a shift in the whole confidence intervals for means estimated for each part of the distribution. 
19. We now look more closely at the dynamic properties of the income distribution, using information from our three panel waves that comprise households continuously surveyed during the whole year. A picture of significant income mobility emerges.

20. Table 4 gives some sense of mobility across consumption quintiles in one year. It shows that for one typical panel wave only up to 30 percent of households in quintiles 2-4 stayed in the same quintile at the end of the period. For these quintiles, mobility is not bound to moving to a neighboring quintile, but involves rather large shifts. Households grouped in the bottom and top quintiles had notably higher survival rates in the range of 40-50 percent.

21. The fact that the highest stability can be found in the lowest quintile also tells us something about the stability of poverty distributions. Interestingly, stability in three subsequent panels is becoming larger over time, suggesting that some of the initial volatility has abated ${ }^{5}$. However, the majority of households are still unsettled in their position in the distribution. Nevertheless, the evidence strongly cautions against assuming that shifts in the income distribution tend to be permanent and cautions against making categorical statements about winners and losers in the transition.

22. A more restrictive exercise does, however, seem warranted by these findings. That is, we know that roughly 7 percent of the population have remained in the upper income quintile. What are the characteristics of this "better-off" group? In other words, what is the profile of the persistently rich, and is it different from the profile of those who are persistently poor (see Chapter 2).

23. "Winners" clearly tend to be located in richer regions, i.e., in predominantly urban areas. For example, in urban Adjara, as many as 31 percent of all households remained in the upper quintile. As a result, 12 percent of the better-off in Georgia reside in urban Adjara (while its share in the population is less than 5 percent). In Samegrelo, both in urban and rural areas, about 12 percent of households are in this "rich" group. Contrary to what one may expect, the rich are not exclusively concentrated in Tbilisi: only about 20 percent of the "better-off" households in Georgia are found there. An interesting contrast arises in Samtskhe-Javakheti - while none of the urban households have managed to stay in the upper quintile, 11 percent of rural households did.

24. There is an unambiguous preponderance of self-employed outside of agriculture in the category of successful households; as many as 35 percent of all "rich" have a self-employed head outside agricultural occupations. Individual entrepreneurs, employers or collective entrepreneurs (cooperative members) outside agriculture are the group that has the highest share of "rich" among all the employed (48 percent of all these entrepreneurs are in the top quintile). Interestingly enough, among the group of stayers in the top quintile we find 5 percent of households that do not have anyone gainfully employed, suggesting an importance of private transfers and remittances for some (better-off) households. The share of "rich" households where the head is employed by the Government is higher (20 percent of all "rich" households) than their share in the population, while the opposite is true for self-employed in agriculture (only 25 percent of "winners" are households headed by self-employed in agriculture).

5 Only 23 percent of individuals in the lowest quintile in 3rd quarter of 1996 remained there one year later, compared to 51-52 percent in the subsequent rounds; similarly, the upper quintile is becoming more stable (only 37 percent of those who were in the top quintile stayed there one year later for the first wave; this proportion has gradually increased to 44 and 48 percent in second and third waves). 
25. The largest group of wage earners in the households that managed to stay in the top quintile for one year of observations is that group employed by the Government (close to 60 percent). However, those employed in the private firms have a much higher chance to be among the "winners" (17 percent of private firm employees are in the households that stayed in the top quintile). The small size of de nuovo private sector explains the relatively small share of private firm employees among the rich (only 5 percent).

26. There is a clear positive link from the educational status of the household head to being a winner. For example, the share of those with higher education among the "rich" is 34 percent, far exceeding their share in the population. On the other hand, only 8 percent of adult individuals in the group of successful households have not completed secondary education - less than half their share in the working age population.

27. In the rural areas, successful households also tend to be associated with larger land holdings, and more diversified crops (including wheat and corn). They also have large money income from farming activities (145 lari per month), about 4 times higher than for an average rural household.

28. It is important that the income structure of the "rich" does not show any domination of unreported income. In fact, its share for the rich ( 25 percent) is lower than for the population on average. It is important and very informative for policy analysis that economic success is closely associated with a greater "visibility" of employment and income, and with higher reliance on formal sources.

29. Thus, our analysis of "rich" reinforces the conclusion of the poverty profile: indeed, the labor market position and productive asset ownership of the better-off part of the population is quite different from the poor. Labor market and earning opportunities seem to be the key to determining the shape and stability of income distribution. However, a very substantial part of the economy for the majority of Georgian households remains barter or "gray", and the part that is "visible" offers a very bleak picture as we shall see next.

\section{Inequality in incomes}

30. Turning to the share of monetary income appropriated by each quintile, Table 5 shows a world of extreme inequities. Extremely high inequality for monetary income is due to high inequities at both ends of the distribution, with the lowest 20 percent of the population commanding only about 1 percent of total income, while the richest 20 percent of individuals had initially a share that exceeded 60 percent. The value of the Gini coefficient at the start $(0.59)$, falls just slightly short of reaching the highest levels observed in the world (Brazil in 1995 had Gini for per capita income at 0.61 ).

31. Over time there has been a considerable improvement in the distribution. The lowest four quintiles experienced an unambiguous increase in their share. The poorest quintile indeed can be seen to have doubled its original share in total income, while the top quintile lost around 10 percent. Inequality indices sensitive to different parts of the distribution show that improvements have affected the entire spectrum of incomes. If we look at the distribution between households, the same positive shifts are noticeable. 
32. However, inequality remains extremely high and close to those levels observed in most Latin American countries. It is also surprisingly high given the methodology of constructing the monetary income aggregate. It reports values of current monetary incomes averaged for the last three months preceding the interview, and thus one may expect a much "smoother" picture. As we have argued before, monetary incomes give only a very partial view of the living standards in Georgia, both because of the high incidence and share of unreported incomes, and because of the consumption of owned agricultural produce in-kind ${ }^{6}$. But extremely high values of Gini (around $0.6)$ are not pure statistical artifacts. It reflects actual instability of incomes over time for most of the population and a low attachment of the majority of the population to the formal sector, where reported money incomes predominately originate.

33. Conclusions for section 3.1: In short, the household data shows that Georgia emerges as the country with significant inequality, and this inequality seems to slowly respond to growth. The inequality indices show a very slow improvement over the period, at least when looking at per capita consumption and incomes. There were significant fluctuations in consumption between rounds, but taking a look at the whole period of observation from mid-1996 through to the end of 1997, there was a clear increase in consumption. That increase was more or less evenly distributed, with some signs of progressivity. This, however, is not enough to make the story a happy one, as inequality remains at high levels, and as a substantial part of the Georgian economy remains "invisible" and thus inaccessible to any public action, and where little inferences are possible to draw, let alone propose any action.

\subsection{Explaining inequality}

34. There are two ways to underpin drivers of inequality. First is to look at what income sources contribute most to rising or tempering inequalities. Second is to see what groups of the population are marked by particularly high inequities and how important are inequalities between groups. Both ways are not mutually exclusive and offer different angles, but each way has to rely on its own indicators ${ }^{7}$. The advantage of using the second approach lies in the fact that we are not bound to use a somewhat biased income indicator, and can base the analysis on consumption. However, given the overall lack of data on the personal incomes from national accounts, we must be mindful of using the survey data not only in analyzing the evolution of inequality but also for pinning down the evolution of income components. To understand better the underpinnings and drivers of income inequalities, we turn to main sources of "adjusted" income.

Conceptual framework: drivers and factors of inequality. In general, the reasons why inequality has grown in transition are not difficult to enumerate. Specifically, in FSU countries, they include: (i) explicit and non-trivial asset redistribution; (ii) the emergence and rapid growth of a private sector; (iii) collapse in the size and shift in the composition of Government spending; (iv) the liberalization of wage setting with low minimum wages; and (v) the fall in the participation rates, as well as the temporary but large effects of price liberalization and the inflation tax. Given measurement problems and lags, precise attribution of weights to each of the channels is

\footnotetext{
6 Monetary incomes represent only 75 percent of total reported incomes, and even a smaller share (48 percent) of total consumption. Gini for total income that includes unreported and in-kind income is much smaller initially, but follows the same trend, falling from .45 to .40 by last round.

7 See in more detail Technical Paper 1, Annex 3. It shows that inequality is easily decomposable by income sources, using Gini index and concentration coefficients. Decomposition of the inequality by population groups using the most popular index of inequality -- Gini coefficient -- is not very informative. To do that we must turn to the Theil measures -- the Theil entropy (T) measure and the Theil mean log deviation (L) measure. Both are additively decomposable inequality indices so that aggregate inequality can be represented as a weighted sum of the same index for different groups -- the 'within' groups' component -- plus the value of the index if the income of every person in each group is equal to the mean income of that group -- the 'between' groups component. The Theil L measure has the additional virtue that it is not dependent on income shares, but rather on group population shares, and is thus strictly additively decomposable.
} 
impossible. Even so, certain clear channels are emerging from a closer look at the sources of household income.

35. Earnings dispersion has surely increased in all transition economies, and Georgia is no exception. The distribution of wages seems to widen more substantially than for total income, and we find the Gini coefficient for wages at the level exceeding 0.5. Self-employment and entrepreneurial activity introduces even more inequality in labor income. The widening labor earnings dispersion is the result of increased inequality within both the State and private sectors, and between sectors. As we have seen in Chapter 2 pre-transition earnings reflected weak or even perverse returns to education and skills, and liberalization of wage setting has been consistent with increased returns to education. Private sector wages seem to provide a sizable premium, probably due to higher productivity. In this chapter we will analyze in detail the respective roles of the private and State sectors in generating inequality outcomes by decomposing the inequality by sectors.

36. This common growth in earnings dispersion has been accompanied by dramatic collapse in the wage share from about 60 percent pre-transition to less than a third of the total monetary income by 1996/97. Offsetting this fall was the growth in entrepreneurial income and selfemployment income that has contributed to the increase in inequality. The existence of unreported income makes this story a bit more complicated, as we shall see below, but which in any case, does not temper the emerging inequality. It is quite difficult to assess any consequence of asset redistribution on the inequality, except the more or less transparent case of land privatization. In this chapter we will look closely at factors determining the self-employment and entrepreneurial income, and its contribution to the overall inequality using the decomposition by sources of income.

37. Widespread involvement in the untaxed "gray" of even "black" economy means also that revenues to the Government from either profit or payroll taxes have dwindled, leaving the Georgian Government unable to provide even an effective minimum level of public goods, yet alone influence the inequality outcomes with transfers. To compound matters, aside from the low average levels of transfers, the evidence also points to taxes actually having a regressive distributional effect. A more detailed analysis of distributional consequences of Government safety net is provided in the next section.

38. As regional initial conditions have played an important role in determining earning opportunities, there are serious institutional impediments to factor mobility, and we find that regional factors tend to play an increasing role in determining inequality levels. Therefore, we will also look carefully at the role of inter-regional differences in the overall inequality.

\section{Decomposition of inequality by groups of the population}

39. As incomes are a rather poor indicator of actual levels of living standards, and to understand better the degree and factors behind the observed inequality we have to concentrate on consumption. This, however, allows us to look at the different groups. We first analyze the breakdown by sector of employment, then by the level of education and resume by looking at regional groupings. 
40. The most important dimension of inequality is the role of employment. Figure 4 provides a first look at the distribution of consumption by the sector of employment of household head.

Figure 4. Distribution of the population by per capita consumption according to the employment of the main earner in the household (average for the period of survey, log)

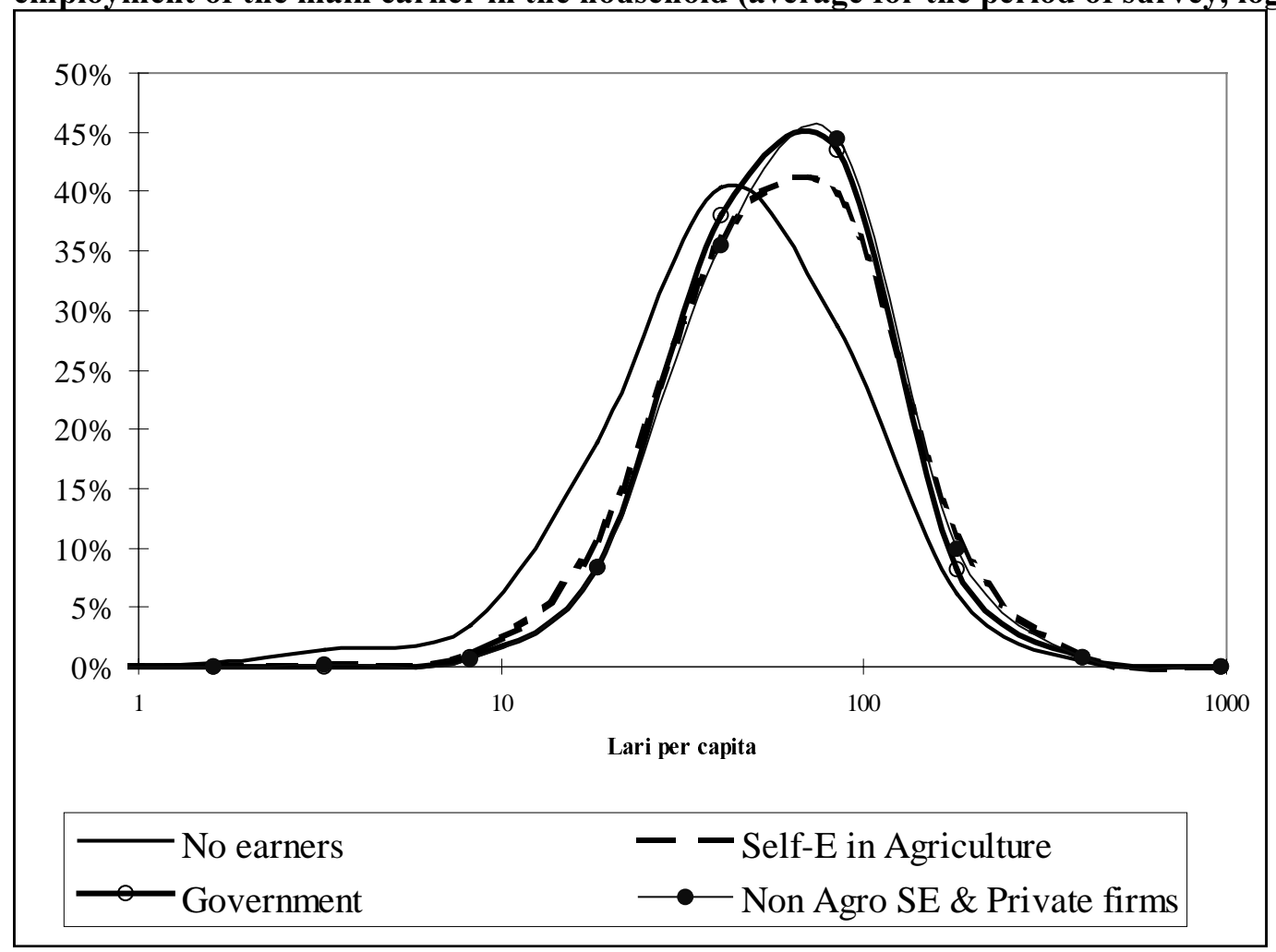

Source: SDS household survey, pooled data, kernel estimates of density function.

41. Figure 4 shows a very clear differentiation of the households with no employed members from the rest of the population: the corresponding curve lies to the left of the other curves, meaning a lower level of consumption. Unemployment clearly has tended to open up the income gap with those in work. The curve is also wider than other curves, pointing to high inequality in this group. However, when we look at other groups of the household, we do not find substantial and large differences between different sectors. Thus the figure tells us that inequality is widespread in any sector, since all curves seem to be quite wide, with the widest one for agriculture. 
42. What Figure 4 does intuitively, Table 6 does in analytical form. It presents average per capita consumption in each group classified according to the employment of the main earner in the household, the extent of inequality by groups, and the contribution of inequality of each group to the overall inequality. It also shows what share of the total inequality, (as measured by the Theil log mean deviation index), is explained by differences in means between groups. As we can see, only 1 percent of the overall inequality can be attributed to differences between sectors of employment. Most of the inequality is coming from within the sectors. In this process, self-employment, both within agriculture and outside agriculture, accounts for over one half of the total inequality. All wage employment, including employment in private firms, generates less inequality than does self-employment or non-employment.

43. As there are clear signs of the increasing role of education in determining wage differentials, we may expect education as being an important factor in inequality. But in fact, differentials between groups (by education) capture only 2 percent of the overall inequality, as Table 7 suggests. Inequality within each group, but primarily among those with secondary education, affects most of the overall inequality. Education acts not by widening of inequalities between education groups, but by rising inequalities within all education groups, where the intensive process of sorting "winners" from "losers" is under way.

\section{Figure 5. Distribution of the population by per capita consumption for selected regions}

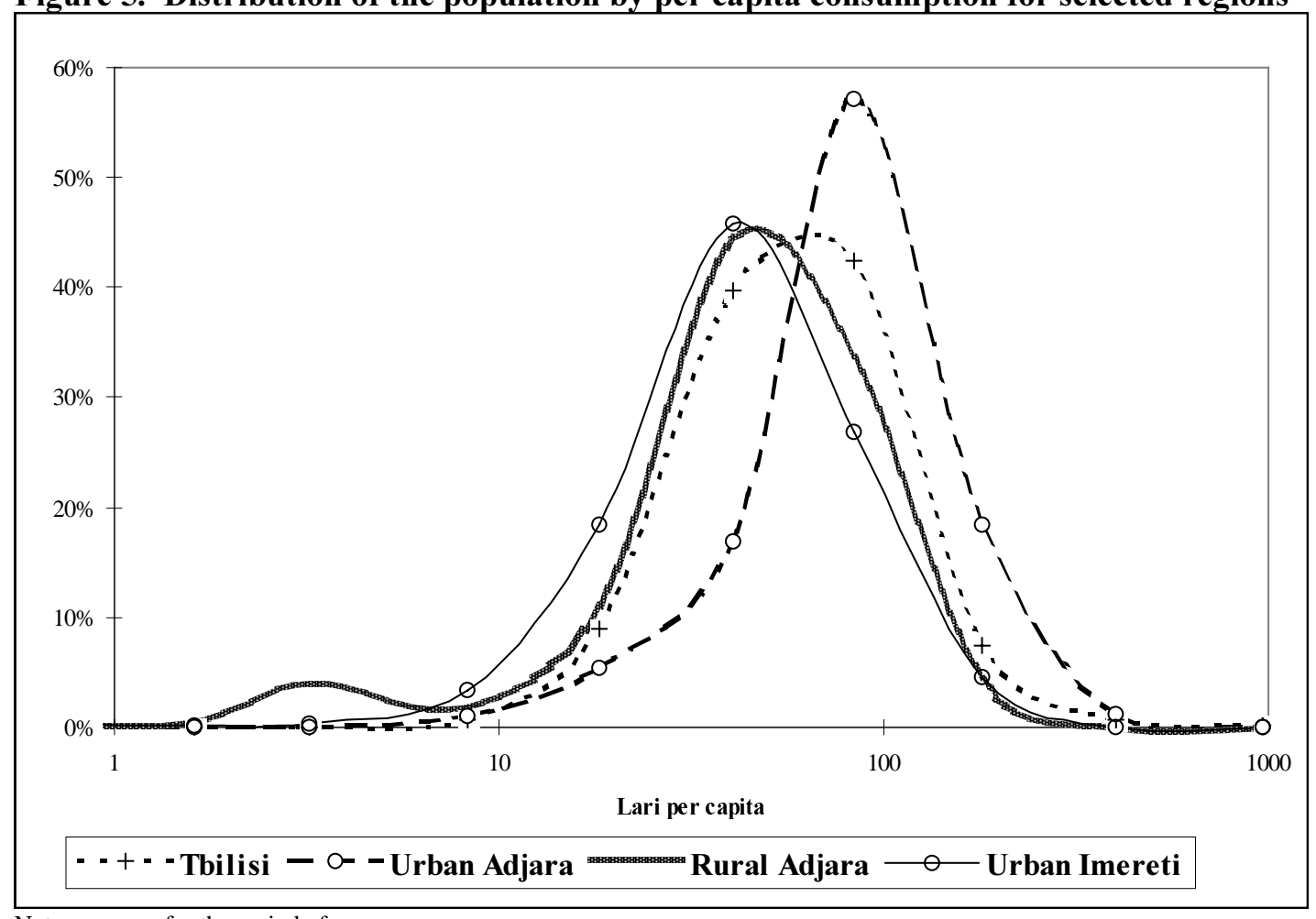

Note: average for the period of survey.

44. Figure 5 suggests the emergence of substantial differences between regions and within regions. The pattern of distribution of population by the level of consumption in urban and rural Adjara is presented by two differently shaped curves with distinctly different humps. There are also some clear differences between other parts of the country, but again, inequality within each region prevails. This is substantiated by Table 8 which provides a decomposition of inequality 
by regions. It shows that inter-regional differences account for only 3 percent of the total inequality ( 6 percent if we treat urban and rural areas in each region separately). Put another way, if all regions had identical mean consumption levels (for example, 70 lari per capita), but consumption differed within groups as it does today, nearly all the inequality would remain (Theil index would change by 3 percent, i.e. from 0.23 to 0.22 - hardly a noticeable change). While at the margin, increases in inter-regional differentials can raise inequality between regions enough to exert some impact on changes in the overall inequality; the actual experience in Georgia with relatively stable overall distribution so far has been the clear predominance of intra-regional factors. And this is despite the quite substantial differences in average per capita consumption, as the same Table shows. Thus, inequality is deeply embedded in every part of Georgia and its economic and social structure.

\section{Decomposition of inequality by income components}

45. To understand better the factors propelling this shift in inequality, we must first look at the composition of income over time. In making this analysis, we use the information available on household incomes. First we look at the structure of incomes by quintiles. Then we do the simplest possible decomposition of inequality by looking at how different income components and total incomes are distributed between quintiles of the population. Notice that while doing this we are using consumption quintiles, (Table 9), which is the key for this section, and which is presenting the distribution of incomes in effect between the rich and the poor (with grades of poverty and affluence). Finally, we analyze factors of inequality in different components, looking at the respective concentration coefficients of the components of income and the contribution of each component to inequality.

46. Overall picture. As Figure 6 reveals, during the survey period, income structure has been relatively stable. However, it should not be forgotten that the structure at the initial point of the survey was quite unusual and different from the pre-transition picture. First, there has been a real collapse in both wages and transfers in the crisis year preceding the survey. Over the period of observation, consistent with the trends observed in Chapter 2, there have been some modest increases in the share of wages from very low initial levels (as the real wages have risen, and wage employment remained practically stable). Transfers have remained relatively stable but constitute a very small share of total income. However, the dominant components of total income are still income from farms (predominantly in non-monetary form), and unreported income. Therefore, the picture of inequality is determined by how unequally these two components are distributed.

47. Decomposition of income inequality by sources of income using quintiles. Table 9 provides a more comprehensive view on the distribution and structure of income separately for urban and rural areas. The main components of total incomes given in Table 9 are: (i) wages and salaries (includes in-kind wages); (ii) income from non-agricultural self-employment (includes own product consumed in-kind); (iii) monetary income from family farm; (iv) State transfers (including humanitarian aid in-kind); (v) remittances from abroad; (vi) private transfers; (vii) in-kind consumption of own agricultural products; (viii) income from assets (interest and rents received, and property sales); (ix) borrowings and savings withdrawal ${ }^{8}$; and (x)

\footnotetext{
8 Our "imputed" measure of income is closer to revenues or cash flow. For example, this involves including loans received as a component of income. While this is not standard practice, there may be some motivation for inclusion in the Georgian context; namely the widespread use of 'loans' as labor payments to avoid taxation; or use as a hidden private transfer mechanism that avoids shame being felt by the recipients. While we have no exact way of determining the share of such loans that are indeed not repayable, inclusion has a limited effect on overall inequality.
} 
"unreported' income, imputed as explained in section $3.1^{9}$. All population is divided in 5 equal groups (quintiles) according to the level of consumption per capita. The first quintile has the lowest consumption, while the 5 th quintile is the richest.

Figure 6. Structure of total income by survey rounds

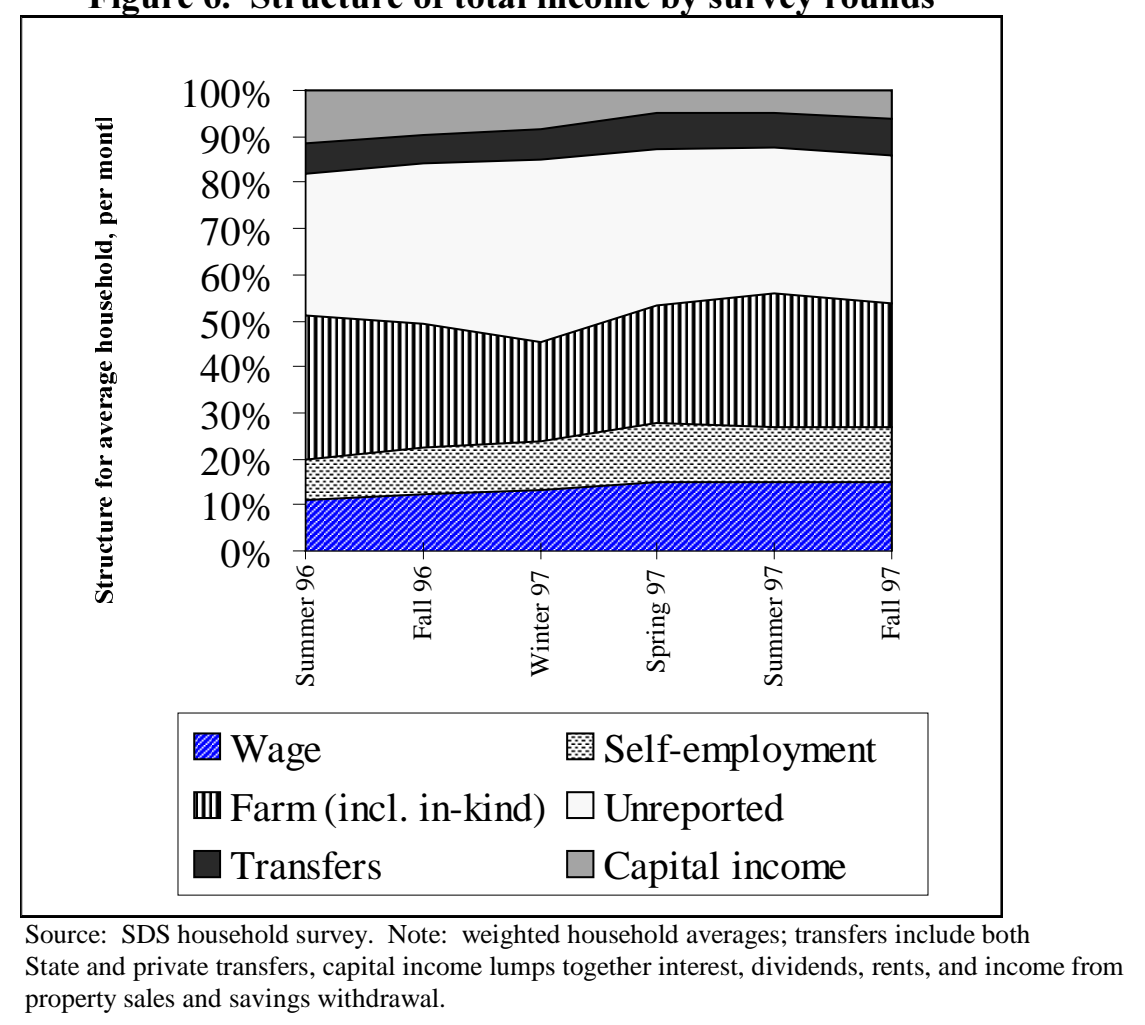

48. Let us first examine in more detail the income structure (upper half of the Table 9), as it determines, to a large extent, the picture of inequality. First, we do observe substantial differences in income structure between urban and rural areas, not only in the role of money and in-kind income from farming, but also in unreported income. Second, in terms of the income structure for different quintiles, in-kind farm products are surprisingly important, both for the lowest and for the highest quintiles. These may in fact show up later, (but not in the survey month), and almost exclusively for the top quintile as farm products sold, but nevertheless, it is notorious that income in-kind is playing a bigger role for the upper quintiles than for the lower quintiles. Third, the role of off-farm earnings is notoriously small for all rural quintiles; it accounts for about a third of total income in urban areas, with self-employment income playing a considerable role in the upper quintiles. Fourth, transfers (both State and private) play an important role for the poorest quintile, but quite a different role in urban and rural areas. Rural poor seem to depend much less on private transfers than do urban poor. Finally, the biggest income item in urban areas for all quintiles is "unreported" income which could represent some "gray" or "black" earnings, remittances or transfers. In rural areas it is clearly less important.

9 Contrary to usual practice, we also include income here in total income, sources of cash that affect asset holdings of the households: we include in total income the reported saving withdrawal, total borrowing, and revenues from selling valubles and property. All this is done with the purpose of minimizing reporting distortions. 
49. To see what determines the overall level of inequality, we now can explore the bottom half of Table 9, looking at how each source of income is distributed between the quintiles. By comparing the shares of quintiles for each source of income with the distribution of total current income between the quintiles, we can tell whether any particular type of income is regressive or progressive. For example, comparing the distribution of self-employment income in urban areas with the distribution of total income, we could see that this source of income is more unequally distributed (lowest quintiles have a lower share, and higher quintiles have a relatively bigger share), and does push the inequality upwards. Another way to express this is to compute the concentration index which we shall refer to below.

50. From a simple inspection of Table 9, we can see clearly the main drivers behind the income inequality. Earnings are definitely playing a disequalizing role. There is a surprising similarity between wage income and non-agricultural self-employment income in terms of how it is distributed between quintiles, but there is more inequality in self-employment income.

However, earnings, just for its small share, is not the main driver of inequality. In-kind produce and income from farming (since these are connected), are both very unequally distributed, and contribute a lot to the overall inequality; in fact it is the main driver of inequality in rural areas. Underlying this are large differences between households in terms of productivity of land holdings that are explained in more detail in Chapter 2. In urban areas, unreported income in conjunction with earnings determines the inequality; all these sources are similarly highly unequally distributed. Remittances and private transfers jointly are less unequally distributed than the total income, but clearly, the rich benefit more from them than the poor do. Only State transfers (mainly pensions) are a progressive element of income, but their small size (3 percent of total income) means that they fail to temper the emerging inequality. We will examine in greater detail the role of State transfers in the next section, and now we will look at the main components of income.

51. Role of labor earnings. All monetary reported earnings are quite unequally distributed with respect to total income. The concentration coefficient for wages is $0.39^{10}$, for selfemployment income it is .49 , and for farm monetary incomes it is .46 , suggesting that the total contribution of earnings to the overall inequality is about 30 percent.

52. Wages, as we have analyzed in Chapter 2, reflect changes in wage setting over transition in a number of key respects. The main reasons behind the wage inequality are emerging differences in pay with respect to human capital. But there are also non-negligible factor of pay inequalities, such as inter-sectoral differences in hours worked, productivity, and prevalence of arrears. Regional factors play a relatively minor role, once controls for sector and job characteristics are introduced. Over time there has been some drop in the own Gini for wages for wage recipients (from levels above 0.5 to levels below .5) accompanied by the increase in the average wage.

53. Self-employment income from off-farm activities is the most unequally distributed source of labor earnings. The determinants of earnings from self-employment may be analyzed in the way that is similar to analyzing wage differentials ${ }^{11}$. We find very strong inter-regional differences witnessing different underlying opportunities for business start-ups in different

10 The concentration coefficient of an income component measures how evenly or unevenly that component is distributed over total household income; negative values tell that it is progressive, i.e. reduces the inequality; values of 0 tells that it is neutral - distributed equally between everybody; any positive value suggests that the source drives the inequality up. In an extreme case value of 1 suggests that the richest household gets all the income. For details of decomposition - see Technical Paper 1, Annex 3.

11 Results of the income regressions reported in this para. are available on request. 
regions. The self-employment income predicted (with a simple regression including only regional dummies and urban/rural locator yields) the Gini index that is just about half of the inequality observed for actual self-employment income. There are also large differences by branch of employment with highest income in construction and lowest in domestic help. Gender gap for primary self-employees (excluding unpaid family workers) is 35 percent, controlling for job and other individual characteristics - a gap similar to gender disparities in wages. This suggests the existence of very important implicit social factors discriminating females on the labor market. And finally, education, though working in the expected direction, is a weak predictor of the level of earnings from self-employment.

54. $\quad$ Farm income and in-kind consumption of agricultural produce. The concentration coefficient for total income from land (in-kind and farm income) is very high, reaching 0.50 . It is just about the most highly unequally distributed source of income. This together with its large share in total income makes it the largest contributor to the overall inequality. Such levels of inequality may in fact be explained by the use of land distribution within the context of social protection and safety nets. Georgian agriculture now consists of small purely subsistence farming household plots, distributed to virtually all rural and many urban citizens, and larger, cash cropping land holdings. However, if we concentrate only on relatively large farmers (over $1 / 2$ ha of land), we find the same picture of persistent inequalities in income from land (own Gini coefficient for land income in this group is as high as 0.55 ). At the same time we do not find big differences between rural households in the land holdings (see Chapter 2), and Gini for arable land in private ownership is only 0.37 . Thus the main factors behind inequality in farm incomes are related to certain patterns of production and differences in the access to information and capital.

55. The issue of informal incomes. Unreported incomes is a large contributor to the overall inequality because of its size, but it is not an exceedingly unequally distributed component (concentration coefficient of 0.4 that is even slightly lower that the Gini for total income). Since it is a very heterogeneous source of income it is difficult to analyze. Except some clear sectoral difference presented in Table 2, here we can also point out some regional discrepancies that are arising as important factors of overall inequality in this component. While in Imereti mean unreported income is only half the national average, in Adjara it is twice the national average. However, over $2 / 3$ of the inequality in unreported income is still unexplained, even after we throw almost all household specific information on demographics, location and occupation that we have. Thus the explanation of the inequality by income components has to remain partially untransparent, as is the Georgian economy nowadays.

56. Conclusions for section 3.2. Factors that have contributed to shifting inequality upwards in the past are unlikely to contribute to raising inequality further, and would, at the least, converge to maintaining current levels. There are, however, some important qualifications. The emerging system remains far from stable; the disintegration of the old system of social relations and political powers is far from complete. There is also surprisingly little evidence of market forces taking over. The distribution factors are dominated either by a small-scale, often subsistence economy, or by the State and by opportunities it offers to individuals that operate on behalf of the State. Thus the consolidation of new classes has yet to be fixed, and the distribution has yet to take its long-term shape. 


\subsection{Distributional impact of social spending}

57. An important channel of income redistribution over the transition involves the evolution of public expenditures, particularly in terms of social protection. The changes are notoriously different in different former socialist economies. One of the peculiarities of the Georgian experience was the complete collapse of public expenditures, and in particular of social spending, with disastrous consequences for the quality and reliability of basic social services, but also for the amount of social transfers from the State budget. In this section we are going to take a look at social spending as revealed by the household survey.

58. The changing role of social spending in household incomes. It is difficult to pin down these changes with any exactitude. Fist the initial conditions are blurred by the fact that the Soviet system of social protection combined a reasonably extensive system of cash transfers with a substantial system of in-kind transfers delivered by a combination of enterprises and government agencies. Moreover, in the context of Georgia, the collapse of the government expenditures in the years of economic crisis with the absence of indexation led to major erosion or lags in benefit values from 1991 onwards. In addition, absence of statistical reporting and survey work in those years does not allow us to pin down changes in the incidence. Working on the assumption that the pre-transition system of transfers was not targeted and largely took the form of a per capita distribution, what we see is a dramatic collapse of economic importance (from nearly 20 percent of household income in pre-transition years to just over 3 percent), and the same poor targeting of State cash transfers that are not inducing a reduction in inequality.

59. The present situation with social transfers as viewed from the household side. The largest State transfer program is presently pensions, and here the decline in benefits over the years of crisis has been almost unbelievable. By now there are some increases in the real value of pensions, though from a very low base, with the number of recipients being roughly stable. By the end of 1997 the average pension was just over 40 percent higher than its nominal value in mid-1996. Other cash transfers have been gradually eliminated (family allowances, child benefits). Unemployment benefits are received by a very small number of recipients and constitute a minor share of total State transfers.

60. So, by 1997 when we talk about cash transfers, we mainly consider pensions. It does not include, however, only old age pensions, but rather the whole array of pension-related benefits (survivors' pensions, disability pensions etc.). State cash transfers also include some other minor components - unemployment benefits and cash assistance from local social protection offices. The overall picture is made more complex by the presence of local governments in social expenditures and in the provision of subsidies to both firms and households. There are also some implicit subsidies related to the provision of some free services for certain groups of population (these forms of social assistance are analyzed in greater detail in Chapter 5). But the overall fiscal envelope for all in-kind of locally provided cash assistance is extremely limited.

61. One important in-kind channel of redistribution is housing. Most of the housing stock in Georgia has been privatized at a symbolic price to its tenants. The Soviet inheritance has meant that until now housing has been very progressively distributed. In addition, utilities have been explicitly or implicitly subsidized. Liberalization of the housing market, the withdrawal of key utility subsidies and enforcement of payment discipline will induce a major redistribution in the absence of a well-targeted system for providing transitional income support. Such a system would require clear specification of the mechanisms -- for example, vouchers or rebates -- for delivering that support and their institutional requirements. 
62. Outside of pensions, very few families are receiving any kind of support from the State. When such support is provided, its level is very low. It is hardly possible to survive on the benefits provided to the household by the State. The very lowest minimum subsistence composed only of bread, corn flour and beans would cost about 40 lari per person per month. None of the benefit provided exceeds 15 lari. This is why all of the benefit recipients have to rely on a variety of sources of income to provide for their most basic needs. The SGH provides the information on the total amount of cash transfers received by the households and the distribution by type of transfer. As we have seen, these transfers constitute a minor share of incomes and consumption (about 3 percent for all population). Further analysis of the poverty profile points out that the groups that receive State transfers tend to be poor.

63. There are some problems, however, in using household data to assess recent changes in the targeting of social assistance. The survey was started at the time when there were child benefits; later this benefit had been replaced by the "social (family) benefit". Unfortunately, the survey instrument has not been changed accordingly, and as of now, there was no way to see how well this new transfer is targeted towards the poor.

64. Incidence of social spending. Information presented in Table 9 indicates that State transfers constitute a sizable 10-12 percent in the incomes of the poorest quintile. This quintile also receives a share of the total transfer that is just a bit higher than its share in the population.

65. Figure 7 illustrates this point very clearly. While there is some evidence of progressivity in the lower part of the distribution, it is on aggregate, slightly worse than no targeting at all (equal distribution to everybody). Public transfers have close to zero, though positive concentration ratios suggest that their distributional incidence has been slightly regressive. However, if we repeat this exercise with respect to consumption rather than income, we get a reversal in the sign of the coefficient, but its value remains practically no different than zero. This suggests that there are some ways to improve the allocation of public funds. Since the exiting pension arrangements are not directly meant to be progressive, there is a clear need for a more radical shift to means-testing for other programs, as resources for these will become available. In addition, the panoply of intransparent in-kind transfer programs with multiple and occasionally inconsistent objectives, points to a need for rationalization. There is an obvious necessity for raising the efficiency of government transfer spending.

66. In sum, the current scale and scope of redistributive Government actions in Georgia is unlikely to be viable in the long-run, not because it is large, but because it is so small and poorly targeted. Without a focused Government action, the prospects of a further rise in inequality can undermine the coherency of society and pose serious political problems. 
Figure 7. Concentration curve for State transfers

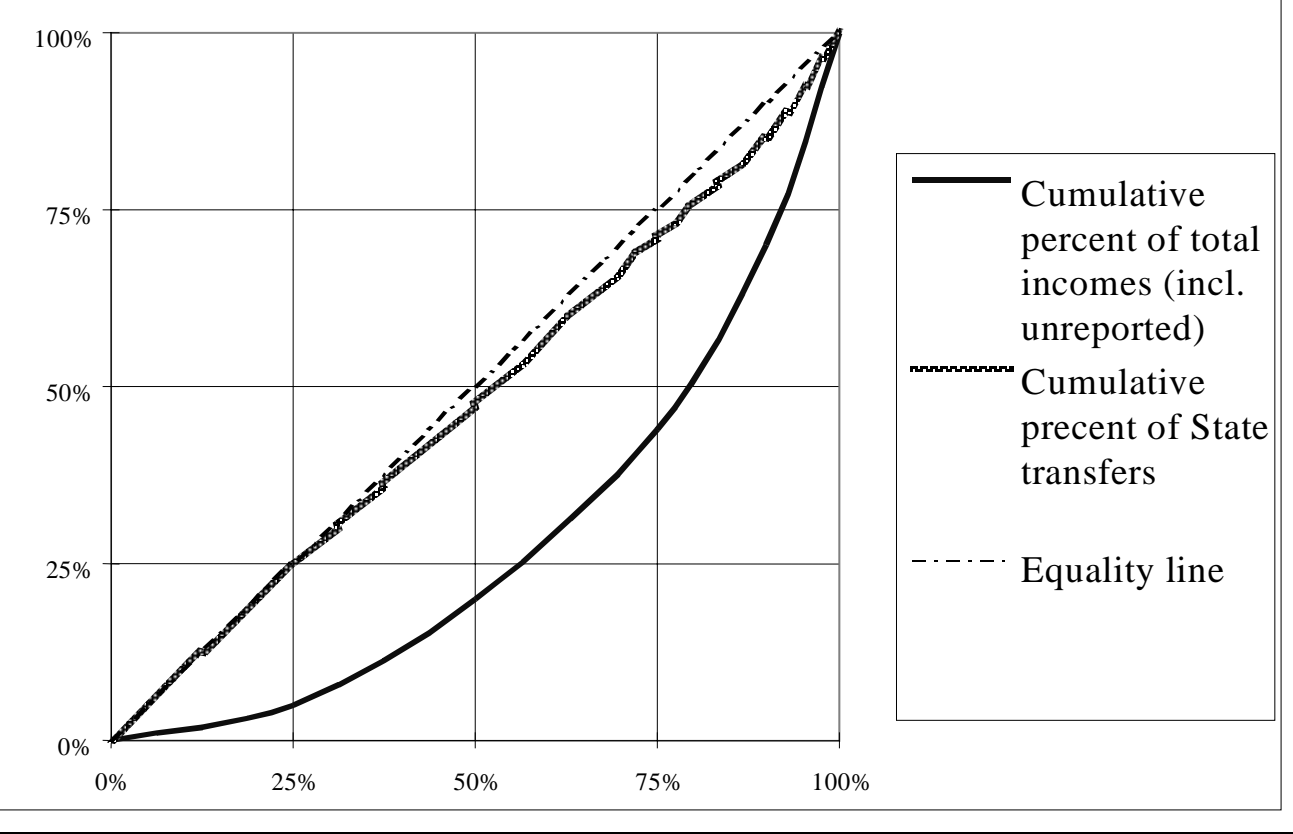

Note: average for the period of the survey.

\subsection{Dimensions of inequality and agenda for action}

67. So far we have concentrated mainly on inequalities that are evident from the survey data. There are, however, serious limitations in using survey data for assessing the overall level of polarization in a society. A good example is a situation in Pakistan. Whenever one looks at the survey-generated numbers, the country consistently appears in the middle range as far as inequality is concerned (Gini for consumption is about 0.3 ). But this ignores the fact that almost half of the nation's wealth belongs to only 20 powerful families that control finances, land and politics of the country, and who never end up being in the survey sampling frame. This is why one has to be careful in attempting broader generalizations from survey data concerning overall social and political agenda.

68. The inequality in Georgia is high, even using the survey-based estimates. The evidence from the qualitative survey (as reported in Dudwick (1996)) suggests an existence of deeplyrooted inequalities related to family, regional and political links. This unequal social tissue is generating the system of considerable economic inequalities. Given Georgia's fragile fiscal situation, public funds for equalization and social protection for the most vulnerable are likely to remain constrained for a long time. Hence, any viable strategy for action must take into account a limited role for public transfers and/or interventions, and focus the role of the State much more on interventions to facilitate the operation of private or non-State mechanisms in order to alleviate extreme inequalities and reduce risk; and also focus on providing an environment which maximizes the opportunities of poor households to help themselves climb out of poverty.

69. There are several areas where the analysis of inequality has identified clear problems and requires public attention. Any proposed measure to enhance equality must be based on a broader dialogue with the civil society. This report is one of the possible vehicles for such a dialogue. 
Therefore we will bound ourselves to list the areas where the proposed discussion should identify viable intervention strategies:

- Inequality between social groups. Those who are unable to work or unable to find work have very limited prospects to be helped privately. There is a clear lack of economic opportunities in rural areas.

- Inequality between regions. Potential inequalities in economic opportunities offered by growth in different regions may become a factor of increasing inequality.

- Inequality in the access to basic services. As education is playing an increasing role on the labor market, providing equitable access to education at reasonable levels of quality will become a challenge. There are now clear forces that drive towards diseqaulization in this respect.

- Gender inequalities. These are not only targeted against the poor, but also generate considerable inequalities on the labor market. 


\section{Decomposing Inequality}

There are two ways of looking at the component of inequality and its changes: using Gini index and using Theil indices. Each has its own uses, advantages and disadvantages. Gini is easily interpretable and allows decomposition by income sources. Theil indices are easier to deal with computationally, but do not have a straightforward interpretation. Their main advantage is decomposability by groups of the population.

\section{Decomposition using Gini index.}

Following A. Shorrocks ("Inequality decomposition by factor components" /Econometrica, 50 (1), 1982, pp.193-211) Gini is decomposed by income components. The contribution of components to total factor inequality, as measured by the Gini coefficient, can be obtained from the product of a "pseudo-Gini" coefficient for each component and a weight of this component in total income. The pseudo-Gini are simply concentration coefficient for a component, that consists of the Gini for the distribution of that particular income component when individuals are ranked in terms of their total (rather than component) income.

Formally Gini coefficient

$$
G=\sum\left[\mu_{k} / \mu\right] G_{k}^{*}
$$

where $\mu_{k} / \mu$ is the share of the component $k$ in total income (the same as mean of component $\mathrm{k}$ to total mean, where missing values are interpreted as zeros). Given that

$$
G=\left\{2 /\left[n^{2} \mu\right]\right\} \sum_{i}\left\{r_{y}-[n+1] / 2\right\} Y_{i}
$$

for $\mathrm{n}$ households indexed by $i$, where $r_{y}$ is the income ranking of total incomes, then the pseudoGini $\mathrm{G}^{*}{ }_{k}$, is obtained in the same way except with $\mathrm{Y}_{k i}$. the $k$ th component of total income, replacing total income $\mathrm{Y}_{i}$. The percentage contribution of inequality in component $k$ to total inequality is

$\left\{\left[\mu_{k} / \mu\right\} G_{k}^{*}\right\} / G$

It can be shown that $\mathrm{G}^{*}{ }_{k} / \mathrm{G}$ is equal to $\operatorname{cov}\left(Y_{k}, r_{k}\right) / \operatorname{cov}\left(Y_{k}, y_{k}\right)$

the rank correlation ratio, where $\mathrm{r}_{k}$ is the income ranking of the $k$ th component.

Using that it is very easy to decompose changes in Gini coefficient into changes due to inequality within the income component, due to the change in share in income component and an interaction term. In section 4.2 we have concentration coefficients by main income components and easily compute their corresponding shares in total inequality by multiplying concentration coefficient by corresponding share of income source.

Moreover, we may explore some experiments with counterfactual scenarios in the income changes. Suppose we consider changes in the income components that multiply each component by a scalar factor and are sufficiently small not to change the overall income ranking. Then $\mathrm{G}^{*} \mathrm{k}$, the concentration coefficient for component $\mathrm{k}$, is unchanged. 
Suppose the share of the component $\mathrm{k}$ changes; we interpret it as both the change in mean of the component from $\mu_{k}$ to ${ }^{\mu^{\prime}}$ and the change in total mean. Then

$$
\begin{aligned}
& G=\left[\frac{\mu_{1}}{\mu}\right] G^{*}{ }_{1}+\ldots\left[\frac{\mu_{k}}{\mu}\right] G^{*}{ }_{k}+\ldots+\left[\frac{\mu_{n}}{\mu}\right] G^{*}{ }_{n} \\
& G^{\prime}=\left[\frac{\mu_{1}^{\prime}}{\mu}\right] G^{*}{ }_{1}+\ldots\left[\frac{\mu_{k}^{\prime}}{\mu^{\prime}}\right] G^{*}{ }_{k}+\ldots+\left[\frac{\mu_{n}^{\prime}}{\mu^{\prime}}\right] G^{*}{ }_{n}
\end{aligned}
$$

$$
G-G^{\prime}=\left[\frac{\mu_{1}}{\mu}-\frac{\mu_{1}^{\prime}}{\mu}\right] G^{*}{ }_{1}+\ldots\left[\frac{\mu_{k}}{\mu}-\frac{\mu_{k}^{\prime}}{\mu^{\prime}}\right] G^{*}{ }_{k}+\ldots+\left[\frac{\mu_{n}}{\mu}-\frac{\mu_{n}^{\prime}}{\mu^{\prime}}\right] G^{*}{ }_{n}
$$

Unfortunately, decompositions of Gini by population groups are not very informative. For that purpose, another class of inequality measures id used.

\section{Decomposition using Theil indices}

Decomposition by population groups allows us to look more closely at the cases of inequality in the components of incomes and expenditures. Following F.Bourguignon ("Decomposable Income Inequality Measures", /Econometrica, 47(4), 1979, pp.901-20) and A.Shorrocks ("The Class of Additively Decomposable Inequality Measures"/ Econometrica 48(1), 1980, pp. 61325).we may decompose total inequality using the Theil indices. It allows as for any given grouping of the population to assess the extent to which total expenditure and income inequality is due to between-groups or within-groups differences.

There are two indices originally proposed by Theil: entropy measure and mean log deviation measure. There is symmetry between those two indices (see below), both are computed by STATA, but the computational simplicity makes the mean deviation measure more appealing.

Let $\mathrm{y}$ be an income (expenditure) of $i$ the household (out of $\mathrm{n}$ ). The entropy index $T$ thus looks as:

$$
T=\frac{1}{n} \sum_{i} \frac{y_{i}}{\mu} \log \frac{y_{i}}{\mu}
$$

where the mean income $\mu=\sum_{i} y_{i} / n$.

Partition of the population into $G$ disjoint groups where subgroup $\mathrm{g}$ consists of $\mathrm{n}_{\mathrm{g}}$ households with the mean $\mu_{g}$

Unfortunately, the use of this index is limited, since it is decomposable by population groups only through income-weighting. To get a more useful and simple measure, ones is using a modification of entropy index, developed by Theil, that is decomposable only be population shares (not including income shares). This index $\mathrm{T}_{0}$ has the following form:

$$
T_{0}=\frac{1}{n} \sum_{i} \log \frac{\mu}{y_{i}}
$$


which is equivalent to what is called Theil mean log deviation index $L$ :

$$
L=\log \left(\frac{1}{n} \sum_{i=1}^{n} y_{i}\right)-\frac{1}{n} \sum_{i=1}^{n} \log y_{i}
$$

That is basically the difference between log of mean income (expenditure) and mean of log incomes (expenditures). This index is remarkably easy to compute.

Both measures are symmetrical in a sense that $\mathrm{L}$ and $\mathrm{T}$ are dual measures. If the weight of $i$ th group in population is given by $\mathrm{w}$, and the income (expenditures) share by $\mathrm{v}$, we have the following basic formula for decomposing total inequality in the within-groups (first term) and between-groups (second term) components:

$$
L=\sum_{i=1}^{m} w_{i} L_{i}+\sum_{i=1}^{m} w_{i} \log \frac{w_{i}}{v_{i}}, \quad T=\sum_{i=1}^{m} v_{i} T_{i}+\sum_{i=1}^{m} v_{i} \log \frac{v_{i}}{w_{i}},
$$

where $L i$ and $T i$ are Theil mean log deviation and Theil entropy indexes for $i$ th group.

From here it becomes obvious that two decompositions are possible, but the $\mathrm{L}$ index is superior, since it is not dependent on the incomes shares. The question such as "How much inequality can be attributed to variation between different household in different regions" might have two meanings: (i) How much less inequality we would observe if regional differences is the only source of income differences and (ii) by how much would inequality fall if region-related differences were eliminated. Only by using L measure we are getting numerically equivalent answer to these two questions.

This mean log differences index $\mathrm{L}$ allows for very simple decompositions. If the total inequality is divided in component B - between groups and C - within groups, it could be found in the following way:

$$
\begin{aligned}
& B=\frac{1}{n} \sum_{g} n_{g} \log \frac{\mu}{\mu_{g}} \text { plus the contribution of inequality within each subgroup } \mathrm{g}=1, \ldots G \\
& C_{g}=\frac{1}{n} \sum_{i=1}^{n_{g}} \log \frac{\mu_{g}}{y_{i}^{g}} .
\end{aligned}
$$

Since we are interested in the trend in two major components, we need not to know the second term, but derive it as a residual between the $\mathrm{B}$ and total value of $\mathrm{L}$.

In Tables 6,7 and 8 we present such decomposition using different classifications. The bulk of inequality in each case can be attributed to the within-classes components. Nonetheless, a sizable portion of inequality as represented by this particular summary statistics is the result of betweengroup differences. These differences seem to be particularly persistent for regional groupings. 
Table 1. Average income and consumption by consumption quintiles

\begin{tabular}{|c|c|c|c|c|c|c|c|}
\hline & Summer 96 & Fall 96 & Winter 97 & Spring 97 & Summer 97 & Fall 97 & $\begin{array}{r}\text { Average for } \\
\text { all quarters }\end{array}$ \\
\hline Mean income per capita, lari/month & 44.93 & 41.84 & 34.64 & 46.52 & 41.80 & 46.42 & 42.69 \\
\hline Median income per capita, lari/month & 27.45 & 24.33 & 22.39 & 29.84 & 28.63 & 29.20 & 26.68 \\
\hline Mean consumption per capita, lari/month & 65.53 & 64.38 & 75.69 & 87.89 & 62.09 & 72.10 & 71.28 \\
\hline $\begin{array}{r}\text { Median consumption per capita, } \\
\text { lari/month }\end{array}$ & 52.15 & 52.43 & 63.03 & 67.02 & 50.54 & 59.84 & 57.32 \\
\hline \multicolumn{8}{|c|}{ Distribution of income per capita by quintiles, lari/month } \\
\hline First consumption quintile (poorest) & 18.20 & 16.66 & 14.26 & 14.43 & 16.62 & 17.62 & 16.30 \\
\hline Second quintile & 26.04 & 26.02 & 20.37 & 23.61 & 23.24 & 25.18 & 24.08 \\
\hline Third quintile & 34.21 & 29.76 & 27.39 & 31.10 & 34.46 & 34.12 & 31.84 \\
\hline Fourth quintile & 47.44 & 42.79 & 37.91 & 42.02 & 45.66 & 47.78 & 43.93 \\
\hline Fifth consumption quintile (richest) & 98.80 & 94.05 & 72.81 & 104.25 & 88.69 & 107.32 & 94.32 \\
\hline \multicolumn{8}{|c|}{ Distribution of consumption per capita by quintiles, lari/month } \\
\hline First consumption quintile (poorest) & 20.16 & 18.59 & 22.49 & 25.53 & 20.65 & 23.01 & 21.74 \\
\hline Second quintile & 36.47 & 37.18 & 43.14 & 45.70 & 36.44 & 42.75 & 40.28 \\
\hline Third quintile & 52.07 & 52.65 & 63.08 & 63.86 & 50.88 & 59.71 & 57.04 \\
\hline Fourth quintile & 74.28 & 73.11 & 89.60 & 89.69 & 71.20 & 82.49 & 80.06 \\
\hline Fifth consumption quintile (richest) & 144.73 & 140.54 & 159.98 & 185.02 & 130.60 & 152.56 & 152.24 \\
\hline \multicolumn{8}{|c|}{ Discrepancy, income - consumption (lari per capita and percent of consumption on average) } \\
\hline First Quintile (poorest) & -1.96 & -1.93 & -8.22 & -11.10 & -4.02 & -5.39 & $-25 \%$ \\
\hline Second Quintile & -10.43 & -11.16 & -22.77 & -22.10 & -13.20 & -17.57 & $-40 \%$ \\
\hline Third Quintile & -17.86 & -22.88 & -35.69 & -32.76 & -16.41 & -25.59 & $-44 \%$ \\
\hline Fourth Quintile & -26.84 & -30.33 & -51.69 & -47.67 & -25.54 & -34.70 & $-45 \%$ \\
\hline Fifth Quintile (richest) & -45.94 & -46.49 & -87.17 & -80.76 & -41.91 & -45.23 & $-38 \%$ \\
\hline
\end{tabular}

Source: SDS Household Survey database. Note: due to changes in methodology of collecting data on in-kind income and consumption, data for the last

two quarters are not fully comparable to previous quarters. For the full sample in each round, quintiles are based on total nominal (non-deflated)

consumption per capita, including consumption of food in kind; incomes also include consumption in kind. All quarterly data are weighted averages

using survey weights, average over the period of observation is an unweighed mean for all quarters.

Table 2. Income, consumption and estimate of unreported monetary income by sector of employment, average per household for the period of survey.

The branch of employment of household Consumption per Total income Gap between monetary spending head household, per household, and monetary incomes, lari/month lari/month lari/month

\begin{tabular}{lccc}
\hline All are unemployed or inactive & 279 & 141 & 95 \\
Agriculture & 274 & 181 & 65 \\
Mining & 322 & 172 & 72 \\
Manufacturing & 279 & 160 & 88 \\
Electricity, gas and water & 240 & 105 & 102 \\
Construction & 316 & 299 & 84 \\
Trade & 239 & 159 & 70 \\
Hotels and restaurants & 411 & 173 & 271 \\
Transportation, communications & 352 & 243 & 106 \\
Financial services and real estate & 343 & 314 & 16 \\
Public administration, defense & 286 & 153 & 107 \\
Education & 245 & 146 & 101 \\
Health and social services & 261 & 130 & 113 \\
Other personal services & 223 & 100 & 83 \\
Domestic help & 237 & 135 & 64 \\
Total & & & 79.83 \\
\hline
\end{tabular}

Note: Samle is restricted to households that provided an information on labor market status of household head. Therefore it is slightly different from Table 1, and some summaries may vary. 
Table 3. Distribution of consumption by consumption quintiles and inequality

$\begin{array}{llllll}\text { Summer } 96 & \text { Fall } 96 & \text { Winter } 97 & \text { Spring } 97 & \text { Summer } 97 & \text { Fall } 97\end{array}$

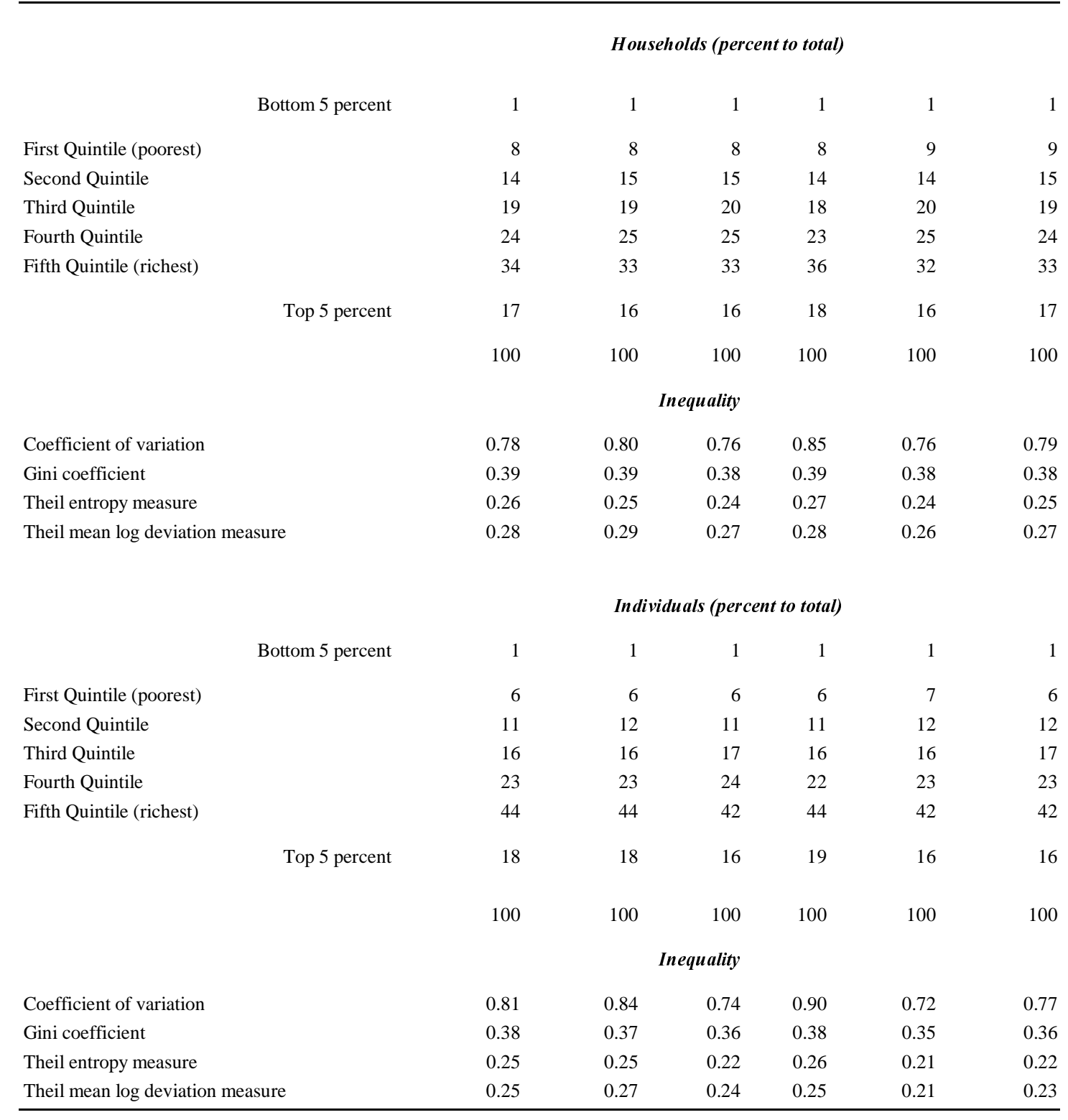

Table4. Transitions between consumption quintiles (second wave of the panel).

Final position (last round, 4 quarters later)

\begin{tabular}{|c|c|c|c|c|c|c|c|}
\hline & & $\begin{array}{r}1 \mathrm{st} \\
\text { quintile } \\
\end{array}$ & $\begin{array}{r}2 \text { nd } \\
\text { quintile }\end{array}$ & $\begin{array}{r}3 \text { rd } \\
\text { quintile } \\
\end{array}$ & $\begin{array}{r}4 \text { th } \\
\text { quintile } \\
\end{array}$ & $\begin{array}{r}5 \text { th } \\
\text { quintile } \\
\end{array}$ & Total \\
\hline \multirow{5}{*}{ Starting position, 1st round } & 1st quintile (Poorest) & $52 \%$ & $19 \%$ & $13 \%$ & $8 \%$ & $7 \%$ & $100 \%$ \\
\hline & 2nd quintile & $26 \%$ & $28 \%$ & $22 \%$ & $13 \%$ & $10 \%$ & $100 \%$ \\
\hline & 3rd quintile & $19 \%$ & $25 \%$ & $30 \%$ & $15 \%$ & $11 \%$ & $100 \%$ \\
\hline & 4th quintile & $11 \%$ & $12 \%$ & $21 \%$ & $30 \%$ & $26 \%$ & $100 \%$ \\
\hline & 5th quintile (Richest) & $4 \%$ & $6 \%$ & $20 \%$ & $25 \%$ & $44 \%$ & $100 \%$ \\
\hline
\end{tabular}

Note: Quintiles are based on per capita consumption, sample restricted to panel households. 
Table 5. Distribution of current monetary incomes by income quintiles and inequality

\begin{tabular}{|c|c|c|c|c|c|c|c|}
\hline & Summer 96 & & Winter 97 & Spring 97 & Summer 97 & Fall 97 & \\
\hline & \multicolumn{7}{|c|}{ Households } \\
\hline First quintile (poorest) & 1 & 1 & 1 & 2 & 2 & 2 & \\
\hline Second quintile & 5 & 5 & 6 & 6 & 6 & 6 & 7 \\
\hline Third Quintile & 11 & 11 & 13 & 12 & 13 & 3 & 13 \\
\hline Fourth quintile & 21 & 22 & 23 & 22 & 23 & & 22 \\
\hline Fifth Quintile (richest) & 62 & 61 & 57 & 60 & 57 & & 56 \\
\hline coefficient of variation & 1.57 & 1.52 & 1.41 & 1.58 & 1.18 & & 1.20 \\
\hline Gini coefficient & 0.60 & 0.59 & 0.55 & 0.57 & 0.55 & & 0.53 \\
\hline Theil entropy measure & 0.69 & 0.65 & 0.55 & 0.61 & 0.52 & & 0.50 \\
\hline \multirow[t]{2}{*}{ Theil mean log deviation measure } & 0.50 & 0.52 & 0.45 & 0.52 & 0.47 & & 0.46 \\
\hline & \multicolumn{7}{|c|}{ Individuals } \\
\hline First quintile (poorest) & 1 & 1 & 2 & 2 & 2 & 2 & 2 \\
\hline Second quintile & 6 & 6 & 7 & 6 & 7 & 7 & \\
\hline Third Quintile & 11 & 12 & 13 & 12 & 13 & & 13 \\
\hline Fourth quintile & 21 & 22 & 23 & 22 & 23 & & 22 \\
\hline Fifth Quintile (richest) & 61 & 59 & 56 & 58 & 55 & & 55 \\
\hline coefficient of variation & 1.61 & 1.51 & 1.31 & 1.60 & 1.25 & & 1.22 \\
\hline Gini coefficient & 0.59 & 0.57 & 0.54 & 0.56 & 0.52 & & 0.51 \\
\hline Theil entropy measure & 0.67 & 0.63 & 0.52 & 0.60 & 0.49 & & 0.48 \\
\hline Theil mean log deviation measure & 0.46 & 0.49 & 0.42 & 0.50 & 0.42 & & 0.43 \\
\hline
\end{tabular}

Table 6. Inequality in consumption by sector of employment, 4th quarter 1997

\begin{tabular}{|l|c|c|c|c|}
\hline \multirow{2}{*}{$\begin{array}{l}\text { Sector of employment of main } \\
\text { earner in a household }\end{array}$} & $\begin{array}{c}\text { Inequality } \\
\text { Average per } \\
\text { capita } \\
\text { consumption, } \\
\text { lari per month }\end{array}$ & $\begin{array}{c}\text { Gini } \\
\text { coefficient for } \\
\text { per capita } \\
\text { consumption }\end{array}$ & Theil index & $\begin{array}{c}\text { Contribution of } \\
\text { inequality within } \\
\text { and } \\
\text { between sectors to total } \\
\text { inequality }\end{array}$ \\
\hline Inactive or unemployed & 60.54 & 0.36 & 0.24 & 8 \\
Self-employed in agriculture & 68.80 & 0.39 & 0.27 & 32 \\
Employed in budget sphere & 75.66 & 0.34 & 0.21 & 14 \\
Employed in SOE & 72.67 & 0.33 & 0.20 & 8 \\
Employed in private firm & 78.10 & 0.32 & 0.17 & 25 \\
Self-employed outside agriculture & 74.03 & 0.36 & 0.22 & 1 \\
& & & Between sectors-> & $\mathbf{1 0 0}$ \\
\hline
\end{tabular}


Table 7. Inequality by education of the household head, average for the survey period

\begin{tabular}{|l|c|c|c|c|}
\hline \multirow{2}{*}{$\begin{array}{l}\text { Highest level completed education } \\
\text { of main earner in household }\end{array}$} & \multirow{2}{*}{$\begin{array}{c}\text { Average per } \\
\text { capita } \\
\text { consumption, lari } \\
\text { per month }\end{array}$} & $\begin{array}{c}\text { Gini coefficient } \\
\text { for per capita } \\
\text { consumption }\end{array}$ & Theil index & $\begin{array}{c}\text { Contribution of } \\
\text { inequality within } \\
\text { sector to total } \\
\text { inequality }\end{array}$ \\
\hline No one is employed & 55.62 & 0.43 & 0.34 & $17 \%$ \\
Less than elementary & 70.32 & 0.29 & 0.14 & $0 \%$ \\
Elementary & 65.48 & 0.38 & 0.24 & $9 \%$ \\
Uncompleted secondary & 62.82 & 0.37 & 0.24 & $11 \%$ \\
Secondary & 71.01 & 0.37 & 0.23 & $28 \%$ \\
Post Secondary & 73.59 & 0.37 & 0.24 & $16 \%$ \\
University and higher & 82.31 & 0.36 & 0.22 & $17 \%$ \\
& & & & \\
& & & Between education levels & $2 \%$ \\
Total & $\mathbf{7 0 . 1 9}$ & $\mathbf{0 . 3 8}$ & $\mathbf{0 . 2 5}$ & $\mathbf{1 0 0 \%}$ \\
\hline
\end{tabular}

Table 8. Inequality in consumption by regions, 4th quarter 1997

\begin{tabular}{|c|c|c|c|c|c|c|}
\hline \multirow[b]{2}{*}{ Region } & \multirow[b]{2}{*}{$\begin{array}{l}\text { Average per } \\
\text { capita } \\
\text { consumption, } \\
\text { lari per month }\end{array}$} & \multicolumn{2}{|c|}{ Of which: } & \multicolumn{3}{|c|}{ Inequality } \\
\hline & & $\begin{array}{l}\text { Urban } \\
\text { areas }\end{array}$ & $\begin{array}{c}\text { Rural } \\
\text { areas }\end{array}$ & $\begin{array}{l}\text { Gini coefficient for } \\
\text { per capita } \\
\text { consumption }\end{array}$ & $\begin{array}{c}\text { Theil mean log } \\
\text { deviation index } \\
\text { for per capita } \\
\text { consumption }\end{array}$ & $\begin{array}{l}\text { Contribution of } \\
\text { inequality within } \\
\text { and between } \\
\text { regions to total } \\
\text { inequality, } \\
\text { percent }\end{array}$ \\
\hline Kakheti & 74.29 & 75.42 & 74.00 & 0.33 & 0.20 & 9 \\
\hline Tbilisi & 72.75 & 72.75 & & 0.34 & 0.21 & 23 \\
\hline Shida kartli & 76.00 & 58.97 & 85.39 & 0.38 & 0.25 & 11 \\
\hline Qvemo kartli & 79.42 & 108.19 & 64.14 & 0.38 & 0.26 & 12 \\
\hline Samckhe-javakheti & 76.00 & 58.39 & 81.33 & 0.33 & 0.20 & 3 \\
\hline Adjara & 83.82 & 106.92 & 61.89 & 0.37 & 0.25 & 11 \\
\hline Guria & 61.53 & 60.67 & 61.86 & 0.33 & 0.18 & 3 \\
\hline Samegrelo & 73.63 & 73.19 & 73.93 & 0.28 & 0.14 & 6 \\
\hline \multirow[t]{3}{*}{ Imereti } & 57.64 & 48.80 & 65.17 & 0.37 & 0.25 & 20 \\
\hline & & & & \multicolumn{2}{|c|}{ Between regions $->$} & 3 \\
\hline & & & & \multicolumn{2}{|c|}{ Separating urban/rural-> } & 6 \\
\hline Total & 72.10 & 73.18 & 70.90 & 0.36 & 0.23 & 100 \\
\hline
\end{tabular}


Table 9.

Structure of income sources by consumption quintiles: average 2nd H 1996- 1st H 1997 (percentages to total)

\begin{tabular}{|c|c|c|c|c|c|c|c|c|c|c|c|}
\hline URBAN & Wages & $\begin{array}{c}\text { Self- } \\
\text { employment } \\
*\end{array}$ & Farm income & $\begin{array}{l}\text { State } \\
\text { transfers }\end{array}$ & Remittances & $\begin{array}{l}\text { Private } \\
\text { transfers }\end{array}$ & $\begin{array}{l}\text { In-kind } \\
\text { income }\end{array}$ & $\begin{array}{l}\text { Assets } \\
\text { income }\end{array}$ & $\begin{array}{c}\text { Borrowing \& } \\
\text { savings withdrawal }\end{array}$ & $\begin{array}{l}\text { "Unreported" } \\
\text { income }\end{array}$ & Total \\
\hline First quintile (poorest) & 15 & 7 & 0 & 12 & 4 & 7 & 8 & 8 & 3 & 36 & 100 \\
\hline Second quintile & 20 & 12 & 1 & 6 & 1 & 6 & 6 & 5 & 3 & 41 & 100 \\
\hline Third Quintile & 22 & 14 & 1 & 4 & 1 & 4 & 7 & 5 & 4 & 38 & 100 \\
\hline Fourth quintile & 22 & 16 & 1 & 3 & 1 & 4 & 8 & 2 & 2 & 41 & 100 \\
\hline Fifth Quintile (richest) & 17 & 15 & 1 & 1 & 1 & 3 & 9 & 5 & 6 & 41 & 100 \\
\hline ALL URBAN & 19 & 14 & 1 & 3 & 1 & 4 & 8 & 5 & 4 & 40 & 100 \\
\hline RURAL & Wages & $\begin{array}{c}\text { Self- } \\
\text { employment } \\
*\end{array}$ & Farm income & $\begin{array}{l}\text { State } \\
\text { transfers }\end{array}$ & Remittances & $\begin{array}{l}\text { Private } \\
\text { transfers }\end{array}$ & $\begin{array}{l}\text { In-kind } \\
\text { income }\end{array}$ & $\begin{array}{l}\text { Assets } \\
\text { income }\end{array}$ & $\begin{array}{c}\text { Borrowing \& } \\
\text { savings withdrawal }\end{array}$ & $\begin{array}{l}\text { "Unreported" } \\
\text { income }\end{array}$ & Total \\
\hline First quintile (poorest) & 7 & 7 & 13 & 10 & 1 & 3 & 26 & 2 & 6 & 26 & 100 \\
\hline Second quintile & 8 & 7 & 12 & 6 & 0 & 1 & 29 & 1 & 5 & 30 & 100 \\
\hline Third Quintile & 7 & 9 & 13 & 4 & 0 & 1 & 29 & 1 & 5 & 29 & 100 \\
\hline Fourth quintile & 7 & 5 & 15 & 3 & 0 & 1 & 34 & 5 & 4 & 27 & 100 \\
\hline Fifth Quintile (richest) & 5 & 7 & 15 & 2 & 1 & 1 & 41 & 1 & 3 & 24 & 100 \\
\hline ALL RURAL & 6 & 7 & 14 & 3 & 0 & 1 & 35 & 2 & 4 & 26 & 100 \\
\hline
\end{tabular}

ALL RURAL

Distribution of income sources by consumption quintiles: average 2nd H 1996 - 1 st H 1997 (percentages to total)

URBAN
First quintile (poorest)
Second quintile

Second quintile

Third Quintile

Fifth Quintile (richest)

$$
\text { Wages } \begin{gathered}
\text { Self- } \\
\text { employment }
\end{gathered} \text { Farm income } \begin{gathered}
\text { State } \\
\text { transfers }
\end{gathered}
$$

Remittances Private

In-kind
income

Assets
income

Borrowing \& "Unreported"

TOTAL URBAN

\section{RURAL}

$\begin{array}{ccc}5 & 3 & 2 \\ 12 & 10 & 13 \\ 19 & 16 & 10 \\ 25 & 25 & 20 \\ 39 & 46 & 55\end{array}$

24
22
20
17
18

$\begin{array}{ccc}21 & 11 & 7 \\ 10 & 17 & 9 \\ 10 & 18 & 14 \\ 11 & 23 & 23 \\ 48 & 31 & 47 \\ \begin{array}{c}\mathbf{1 0 0} \\ \text { Remittances }\end{array} & \begin{array}{c}\mathbf{1 0 0} \\ \text { Private } \\ \text { transfers }\end{array} & \begin{array}{c}\mathbf{1 0 0} \\ \text { In-kind } \\ \text { income }\end{array}\end{array}$

11
12
16
11
49
$\mathbf{1 0 0}$
Assets
income

avings withdr

Unreported"
income

First quintile (poorest)

Second quintile

Third Quintile

Fourth quintile

100
Wages

Self-
employment

$\mathbf{1 0 0}$
State
transfers

$\begin{array}{cc}8 & 15 \\ 10 & 14 \\ 9 & 17 \\ 21 & 17 \\ 52 & 38\end{array}$

TOTAL RURAL

$\begin{array}{cccc}6 & 6 & 5 & 18 \\ 14 & 12 & 10 & 22 \\ 18 & 21 & 15 & 19 \\ 26 & 17 & 24 & 20 \\ 36 & 44 & 47 & 22\end{array}$

* For non-agricultural activities only.

100

100

100

4
9
14
22
51

4
6
9
52
30
$\mathbf{1 0 0}$

100
Borrowing

Borrowing \&

"Unreported

$\begin{array}{cc}6 & 7 \\ 12 & 12 \\ 15 & 16\end{array}$

14

14

15

23

12

100

100

100

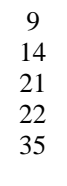

6
13
18
23
40

6 


\section{IZA Discussion Papers}

No Author(s)

161

V. Gimpelson

D. Treisman

G. Monusova

162

C. Dustmann

M. E. Rochina-

Barrachina

R. A. Hart

Y. Ma

164 M. A. Shields

S. Wheatley Price

165

A. Barrett

J. FitzGerald

B. Nolan

G. S. Epstein

A. L. Hillman

R. Winkelmann

T. K. Bauer

K. F. Zimmermann

C. Dustmann

F. Windmeijer

D. Card

D. S. Hamermesh

E. Fehr

J.-R. Tyran

M. Lofstrom

W. Meyer

Titel

Area

Date

Public Employment and Redistributive Politics:

4

$6 / 00$

Evidence from Russia's Regions

Selection Correction in Panel Data Models: An 6

Application to Labour Supply and Wages

Why do Firms Pay an Overtime Premium?

5

$6 / 00$

Racial Harassment, Job Satisfaction and Intentions

5

$6 / 00$

to Quit: Evidence from the British Nursing Profession

Immigration in a High Unemployment Economy: 1

$6 / 00$ The Recent Danish Experience

The Impact of Alcohol Consumption on Occupa- 5 tional Attainment in England

$6 / 00$

Earnings Inequality, Returns to Education and 5 Immigration into Ireland

$6 / 00$

Social Harmony at the Boundaries of the Welfare 3 State: Immigrants and Social Transfers

$6 / 00$

Immigration Policies and their Impact: The Case of 1

$7 / 00$

New Zealand and Australia

Immigration Policy in Integrated National

$7 / 00$

Economies

Wages and the Demand for Health - A Life Cycle 5

$7 / 00$

Analysis

Reforming the Financial Incentives of the Welfare 3

System

$7 / 00$

Timing, Togetherness and Time Windfalls

$7 / 00$

Does Money Illusion Matter? An Experimental

7

$7 / 00$

Approach

Self-Employment and Earnings among High-

Skilled Immigrants in the United States

Industrial Relations and the Wage Differentials

5

$7 / 00$ between Skilled and Unskilled Blue-Collar

Workers within Establishments: An Empirical

Analysis with Data of Manufacturing Firms 
177 B. R. Chiswick

G. Repetto

178 R. Euwals M. Ward

179 E. Wasmer

P. Weil

180 T. K. Bauer

I. N. Gang

181 E. Wasmer

Y. Zenou

182 M. Fertig

C. M. Schmidt

183 M. Fertig

C. M. Schmidt

184 M. Corak

B. Gustafsson

T. Österberg

185

H. Bonin

K. F. Zimmermann

186

C. Dustmann

T. K. Bauer

M. Lofstrom

K. F. Zimmermann

188 A. Kapteyn

A. S. Kalwij

A. Zaidi

189 W. Arulampalam

190

C. Dustmann

I. Preston

191

G. C. Giannelli

C. Monfardini

192

G. Brunello

A. Kunze
Immigrant Adjustment in Israel: Literacy and

Fluency in Hebrew and Earnings

The Renumeration of British Academics

The Macroeconomics of Labor and Credit Market Imperfections

Sibling Rivalry in Educational Attainment:

The German Case

Space, Search and Efficiency

2

Discretionary Measures of Active Labor Market

Policy: The German Employment Promotion Reform in Perspective

Aggregate-Level Migration Studies as a Tool for 1 Forecasting Future Migration Streams

Intergenerational Influences on the Receipt of

3

Unemployment Insurance in Canada and Sweden

The Post-Unification German Labor Market

4

$8 / 00$

Temporary Migration and Economic Assimilation

$8 / 00$

Immigration Policy, Assimilation of Immigrants and Natives' Sentiments towards Immigrants: Evidence from 12 OECD-Countries

The Myth of Worksharing

Is Unemployment Really Scarring? Effects of Unemployment Experiences on Wages

Racial and Economic Factors in Attitudes to Immigration

Joint Decisions on Household Membership and Human Capital Accumulation of Youths: The role of expected earnings and local markets

Absolute Risk Aversion and the Returns to Education

The Determination of Wages and the Gender Wage Gap: A Survey 
195 F. Büchel

A. Mertens

196 J. S. Earle

K. Z. Sabirianova

197

G. A. Pfann

198 M. Kreyenfeld

C. K. Spiess

G. G. Wagner

199 H. Entorf

200 T. Bauer

G. S. Epstein

I. N. Gang

201 T. J. Dohmen

G. A. Pfann

202

P. Francois

J. C. van Ours

203
J. M. Abowd
F. Kramarz
D. N. Margolis
T. Philippon

204

G. S. Epstein
A. L. Booth
M. Francesconi
J. Frank

206 C. M. Schmidt

R. Baltussen

R. Sauerborn

C. M. Schmidt

J. Hartog

R. Winkelmann

209 M. Barbie

M. Hagedorn

A. Kaul

210 T. J. Dohmen
Overeducation, Undereducation, and the Theory

of Career Mobility

Equilibrium Wage Arrears: A Theoretical and 4

Empirical Analysis of Institutional Lock-In

Options to Quit

1

$9 / 00$

A Forgotten Issue: Distributional Effects of Day 3

Care Subsidies in Germany

Rational Migration Policy Should Tolerate Non-

Zero Illegal Migration Flows: Lessons from

Modelling the Market for Illegal Migration

What are Migration Networks?

$9 / 00$

Worker Separations in a Nonstationary Corporate 1 Environment

Gender Wage Differentials in a Competitive Labor Market: The Household Interaction Effect

The Tail of Two Countries: Minimum Wages and 5 Employment in France and the United States

5

$9 / 00$

$9 / 00$

Labor Market Interactions Between Legal and

1

$10 / 00$ Illegal Immigrants

Temporary Jobs: Stepping Stones or Dead Ends? 1

$10 / 00$

The Evaluation of Community-Based Interventions: Group-Randomization, Limits and Alternatives

Arbeitsmarktpolitische Maßnahmen und ihre

6

$10 / 00$

Evaluierung: eine Bestandsaufnahme

Dutch Migrants in New Zealand:

Did they Fare Well?

1

$10 / 00$

Dynamic Effciency and Pareto Optimality in a

3

$10 / 00$ Stochastic OLG Model with Production and Social Security 

211 A. van Soest
M. Das
X. Gong
212 X. Gong
A. van Soest
P. Zhang
213 X. Gong
A. van Soest
E. Villagomez

214 X. Gong

A. van Soest

215 J. Ermisch

M. Francesconi

216 F. Büchel

217 J. Hansen

R. Wahlberg

218 C. Dustmann

A. van Soest

219 F. Kramarz

T. Philippon

220 W. A. Cornelius

E. A. Marcelli

221

C. Grund

222 W.P.M. Vijverberg

223 M. Rosholm

M. Svarer

224

J. Schwarze

225

L. Modesto

J. P. Thomas
A Structural Labour Supply Model with

The Effects of Overeducation on Productivity in Mexico

Wages as Risk Compensation in Germany 

former Soviet Union to Israel: Who is coming when? 

of Labor Income Risk and Car Insurance in the UK 1969-95 Soviet Union: A Study of the Suicide Epidemic in the 1990s

244 S. M. Fuess, Jr.

Pay and Productivity in a Corporatist Economy: 